\title{
Wage-led growth in the EU15 Member States: the effects of income distribution on growth, investment, trade balance, and inflation
}

\author{
Özlem Onaran
}

University of Greenwich

and

\section{Thomas Obst}

University of Greenwich

Acknowledgements: This paper has received funding from the Foundation of European Progressive Studies, TASC, and Irish Congress of Trade Unions for the project titled "WageLed Growth in Europe? Demand Effects of Changes in Functional Income Distribution in Financialised Open Economies."

We would like to thank Engelbert Stockhammer, Mehmet Ugur, Maria Nikolaidi for helpful comments and are grateful for the discussion with participants in the 19th FMM Conference in Berlin 2015. 


\title{
Wage-led growth in the EU15 Member States: the effects of income distribution on growth, investment, trade balance, and inflation
}

\begin{abstract}
This paper estimates a multi-country demand-led growth model for the EU15. A decrease in the share of wages in national income in isolation leads to lower growth in Finland, France, Germany, Greece, Italy, Luxembourg, Netherlands, Portugal, Spain, Sweden and the United Kingdom, whereas it stimulates growth in Austria, Belgium, Denmark and Ireland. However, a simultaneous decline in the wage share leads to an overall decline in the EU15 GDP; hence EU15 as a whole is a wage-led economy. Furthermore, Austria and Ireland also experience a decline in growth when they decrease their wage share along with their trading partners. The results indicate that the decline in the wage share had significant negative effects on growth in the EU15 and supports the case for wage coordination. We present different wage-led recovery scenarios and the effects on prices, investment, and net exports.
\end{abstract}

Key words: Wage Share, Growth, European Multiplier, Demand Regime JEL classifications: E12, E22, E25 


\section{Introduction}

There has been a substantial decline in the share of wages in national income in the majority of the European countries since the 1980s. In contrast to conventional wisdom, this development was associated with a poor growth performance in most European countries. Indeed, the outbreak of the Great Recession in 2007 and slow recovery in the aftermath shed light on the limitations of the conventional growth strategy in Europe.

The Europe 2020 strategy of the European Commission (EC) as well as the national reform and stability programs since the Great Recession repeatedly advocate further deregulation of the labour markets in the name of structural reform, and wage moderation policies, i.e. real wage growth below the rate of growth in labour productivity, to regain global competitiveness, reduce unemployment and create growth (EC, 2011; EC, 2012). Furthermore, internal devaluation is imposed in European member states (MS) with trade deficit (e.g. Greece, Spain, Portugal) with the assumption that this will restore competitiveness, profitability and growth (EC, 2013). According to this thinking, incentivising a reallocation of resources into export-oriented industries, primarily through wage cuts, are the main path to growth-friendly external rebalancing within the Eurozone.

In contrast to this mainstream assumption that wage moderation unambiguously leads to higher growth, this paper presents a theoretical model and an empirical analysis for Europe based on the Post-Keynesian theory, which develops a general theory of the effect of the wage share on investment, net exports, and growth, and suggests that the sign of the effect is an empirical matter, which depends on the structural characteristics of the countries.

We analyse the effect of a pro-capital redistribution of income on growth in a highly integrated region such as the EU15. The model estimated in this paper extends the postKeynesian/post-Kaleckian demand-led growth model developed by Bhaduri and Marglin 
(1990) to a multi-country framework, and aims at analysing the effects of a change in the wage share on growth. ${ }^{1}$ A priori one would expect a falling wage share, i.e. a rising profit share, to have positive direct effects on investment and net exports, but negative direct effect on consumption, since the marginal propensity to consume out of wage income is expected to be higher than that out of profit income. However, the question whether the negative effect of an increasing profit share on consumption overpowers the positive effects on investment and net exports essentially is an empirical one, depending on the relative size of the consumption differential, the sensitivity of investment to profit and the sensitivity of net exports to unit labour costs. If the total effect is negative, the demand regime is called wage-led; otherwise it is profit-led ${ }^{2}$.

The post-Keynesian/post-Kaleckian theoretical framework highlights the central role of demand in determining growth in economies operating below full employment and points out the dual role of wages as a cost item to the firm but also as a source of demand in the economy.

The novelty of this paper is that it integrates cross-country effects of a simultaneous decline in the wage share on demand in Europe. Previous studies have only analysed a subset of European countries (i.e. Onaran and Galanis, 2014; Storm and Naastepad, 2012; Hein and Vogel 2008; Bowles and Boyer, 1995) or taken the Eurozone as a hypothetical aggregate economy without considering cross-country interactions (Stockhammer et al., 2009; Onaran and Galanis, 2014). To the best of our knowledge, Onaran and Galanis (2014) were the first to develop a coherent theoretical and empirical multi-country model for the G20 countries, which inspired the model in this paper.

This paper develops a consistent estimation strategy providing new estimates for all EU15 countries individually, including those previously not covered in the empirical literature. Second, we analyse the effects of a simultaneous fall in the wage share and its impact on 
growth in the EU15 as well as on investment, net exports, and prices based on interactions across countries. The modelling of the total effects on investment, trade balance and inflation integrating national and cross-country multiplier effects is another novelty of this paper. Third, we present a wage-led recovery scenario, and discuss whether coordinated wage policies can promote higher growth with a more equitable income distribution, and present a feasible alternative to the current European strategy of wage restraint.

The paper is structured as follows: Section 2 presents data and stylised facts. Section 3 presents the theoretical model. Sections 4 and 5 discuss the estimation methodology and results. Section 6 compares the findings to the empirical literature and section 7 presents a wage-led recovery scenario. Section 8 concludes.

\section{Data and Stylized Facts}

The definitions and sources of the variables in the model are presented in Appendix A. C, I, $\mathrm{X}, \mathrm{M}, \mathrm{Y}, \mathrm{W}$ and $\mathrm{R}$ are consumption, private investment, exports, imports, GDP at market prices, adjusted wages and adjusted profits in real terms.

Profit share, $\pi$, is adjusted gross operating surplus as a ratio to GDP at factor cost, $Y_{f}$; wage share, $w s$, is $1-\pi$. The adjusted wage share allocates a labour compensation for each self-employed equivalent to the average compensation of the dependent employees ${ }^{3}$. The sample is restricted to EU15 countries ${ }^{4}$, due to a lack of sufficient time series data for the new EU MS. The sample period is 1960-2013.

Figure 1 shows the wage share in the EU15 countries. There is an overall decline in the wage share in the majority of the countries, particularly pronounced between the early 1980s and mid-2000s. The fall is more moderate in Belgium, Denmark, Luxembourg, and the UK. In the UK, this may be due to a sharp increase in managerial income. Greece experienced a pronounced fall in the 1960s coming to a stop with the end of the military dictatorship in the 
mid-1970s. Portugal exhibits an exceptional upswing followed by a significant downswing during the revolutionary period between 1974 and 1976 (Lagoa et al., 2014). Luxembourg, as an outlier, exhibits a significant increase starting in the early 1970s followed by a moderate decline after the early 1980s.

\section{Figure 1}

Overall, the share of wages in national income has declined by roughly 10 percentage points in the EU15 countries between their latest peak levels (in the mid-1970s or early 1980s) and 2013.

The secular decline in the wage share was associated with a weaker growth performance in the majority of countries. For instance, average growth in France declined from $5.7 \%$ in the 1960 s to roughly $2 \%$ in the 1990 s. In Italy, average growth dropped significantly from almost $6 \%$ in the 1960 s to roughly $1.5 \%$ in the 1990 s. However, growth rates increased in the case of Ireland and Luxembourg until the Great Recession in 2008. In the UK, average growth remained relatively stable, with values between $2 \%$ and $3 \%$ between the 1960 s and 2000s.

\section{The Theoretical Model}

We model the effects of a change in the profit share on the level of GDP by analysing the country level effects on the components of private aggregate demand: consumption, investment, exports and imports. We then estimate European interactions resulting from the effects of a change in the profit share of other EU15 countries. The model is based on a postKaleckian framework; however, the behavioural functions also encompass standard Keynesian models (e.g. Blanchard, 2006).

Consumption (C) is a function of adjusted profits (R) and adjusted wages $(\mathrm{W})^{5}$ :

$$
\log C=c_{0}+c_{R} \log R+c_{W} \log W
$$


As in Stockhammer et al. (2009), we calculate the marginal effects of a change in the profit share on $C$ through multiplying the estimated coefficients (elasticities) of $R$ and $W$ by mean values of our sample $C / R$ and $C / W$ respectively.

$$
\frac{\Delta(C / Y)}{\Delta(\pi)}=c_{R} \frac{C}{R}-c_{W} \frac{C}{W}
$$

The estimates are equivalent to the difference in marginal propensity to consume out of profits and wages, and are expected to be negative.

Private Investment (I) is modelled as a positive function of output and the profit share as an indicator for expected profitability as well as the availability of internal finance:

$$
\log I=i_{A}+i_{Y} \log Y+i_{\pi} \log \pi+i_{r} r
$$

where $i_{A}$ is autonomous investment, and all parameters are expected to be positive. As a control variable, we include real long-term interest rate $r$ and is expected to have negative effects on investment ${ }^{6}$. The marginal effect of $\pi$ on $I / Y$ is calculated as follows:

$$
\frac{\Delta(I / Y)}{\Delta(\pi)}=i_{\pi} \frac{I}{R}
$$

We model the effects of distribution on net exports using a stepwise approach that follows Stockhammer et al. (2009), Onaran et al. (2011) and Onaran and Galanis (2014). First, domestic prices $(P)$ and export prices $\left(P_{x}\right)$ are a function of nominal unit labour costs, $u l c$, and import prices, $P m$, based on a mark-up pricing model in an imperfectly competitive economy.

$$
\begin{gathered}
\log P=p_{0}+p_{u l c} \log (u l c)+p_{m} \log (P m) \\
\log P_{x}=p x_{0}+p_{u l c} \log (u l c)+p_{m} \log (P m)
\end{gathered}
$$

Exports $(\mathrm{X})$ are a function of relative prices of exports to imports, $\frac{P x}{P m}$, and GDP of the rest of the world, Yrw:

$$
\log X=x_{0}+x_{p x m} \log (P x / P m)+x_{Y r w} \log (Y r w)+x_{e} \log (E)
$$

We include exchange rate, $E$, as a control variable. 
Imports $(M)$ are a function of domestic prices relative to import prices, $\frac{P}{P m}$, and GDP.

$$
\log M=m_{0}+m_{p p m} \log (P / P m)+m_{Y} \log (Y)+m_{e} \log (E)
$$

Again, we include exchange rate $E$ as a control variable.

We calculate the marginal effect of a change in the profit share on exports/GDP as:

$$
\frac{\Delta\left(\frac{X}{\bar{Y}}\right)}{\Delta(\pi)}=(-)\left(\frac{\partial \log X}{\partial \log P_{X}} \frac{\partial \log P_{\chi}}{\partial \log (u l c)} \frac{\partial \log (u l c)}{\partial \log (\text { rulc })} \frac{\partial \log (\text { rulc })}{\partial \log (w s)}\right) \frac{X / Y}{r u l c}=(-)\left(e_{X P} e_{P X} \frac{1}{1-e_{P}} \frac{Y f}{Y}\right) \frac{X / Y}{r u l c}
$$

where $e_{P x}$ illustrates the effect of nominal unit labour costs $(u l c)$ on $P_{x}$ and $e_{X P}$ is the effect of $P_{x}$ on exports. The wage share is real unit labour costs $(r u l c)$ multiplied by GDP at market prices divided by GDP at factor costs $\left(Y / Y_{f}\right)$. The average values of $\frac{X / Y}{r u l c}$ for the sample mean are used to convert the elasticity to marginal effects. Finally, we take the negation of the total effect. A similar procedure is followed for imports:

$\frac{\Delta(M / Y)}{\Delta(\pi)}=(-)\left(\frac{\partial \log M}{\partial \log P} \frac{\partial \log P}{\partial \log (u l c)} \frac{\partial \log (u l c)}{\partial \log (r u l c)} \frac{\partial \log (r u l c)}{\partial \log (w s)}\right) \frac{M / Y}{r u l c}=(-)\left(e_{M P} e_{P U L C} \frac{1}{1-e_{P U L C}} \frac{Y_{f}}{Y}\right) \frac{M / Y}{r u l c}(10)$

The sum of partial effects of a change in $\pi$ on consumption, investment, and net exports $(N X=X-M)$ is the effect on private excess demand. This, in turn, will further affect consumption, investment, and imports through the multiplier mechanism.

\subsection{Effects of a simultaneous change in the profit share}

Until now, we have ignored the effects due to a simultaneous change in distribution in Europe; however this overestimates the positive effects of a fall in the wage share on net exports. While higher openness of an economy increases the relevance of the positive effects of a fall in the wage share due to a higher share of net exports in GDP, European economies are integrated and, as recommended by the EC, all countries are trying to compete on the basis of wage costs. This decreases the effects of a fall in the wage share on net exports when it is implemented simultaneously in a variety of countries, as relative prices of exports and imports do not change significantly when all countries reduce their nominal unit labour costs. 
Given the high economic integration of the European economy a full understanding of the simultaneous fall in the wage share requires an integrated European wide analysis. In 2013, the greater proportion of a MS's total trade in goods was with partners within the EU-28 with an average of 62\% of total exports (Eurostat, 2015).

In the following, we present the Europe-wide effects of a simultaneous change in $\pi$ based on a multi-country model as in Onaran and Galanis (2014). ${ }^{7}$ To the best of our knowledge, this is the first paper to extend the multi-country model to the EU15 countries based on individual country estimations. This European multiplier mechanism incorporates the effects of a change in $\pi$ on the aggregate demand of each economy through the changes in import prices and the GDP of trade partners. For the case of 15 countries, the percentage change in GDP of each country is:

$$
\left[\begin{array}{c}
\frac{\Delta Y_{1}}{Y_{1}} \\
\vdots \\
\frac{\Delta Y_{15}}{Y_{15}}
\end{array}\right]=E_{15 \times 15}\left[\begin{array}{c}
\Delta \pi_{1} \\
\vdots \\
\Delta \pi_{15}
\end{array}\right]+H_{15 \times 15}\left[\begin{array}{c}
\frac{\Delta Y_{1}}{Y_{1}} \\
\vdots \\
\frac{\Delta Y_{15}}{Y_{15}}
\end{array}\right]+P_{15 \times 15}\left[\begin{array}{c}
\Delta \pi_{1} \\
\vdots \\
\Delta \pi_{n 15}
\end{array}\right]+W_{15 \times 15}\left[\begin{array}{c}
\frac{\Delta Y_{1}}{Y_{1}} \\
\vdots \\
\frac{\Delta Y_{15}}{Y_{15}}
\end{array}\right]
$$

The matrices $E$ and $H$ represent the effects of a change in each country's own $\pi$ on demand in that particular country. $E$ is a matrix, whose diagonal elements are the effect of a change in $\pi$ in country j on private excess demand $(C+I+N X / Y)$ in country j. Matrix $H$ reflects the national multiplier effects and hence shows the effect of an autonomous change in private excess demand on aggregate demand. Matrix $P$ illustrates the effect of a change in trade partners $` \pi$ on import prices and hence on net exports in each country. Finally, matrix $W$ shows effects of a change in trade partners' GPD on exports of each country. The details are in appendix B.

Solving equation (11) for $\left[\frac{\Delta Y}{Y}\right]$ gives us the equivalent of a European multiplier effect:

$$
\left[\begin{array}{c}
\frac{\Delta Y_{1}}{Y_{1}} \\
\vdots \\
\frac{\Delta Y_{15}}{Y_{15}}
\end{array}\right\rfloor=\left(I_{15 \times 15}-H_{15 \times 15}-W_{15 \times 15}\right)^{-1}\left(E_{15 \times 15}+P_{15 \times 15}\right)\left[\begin{array}{c}
\Delta \pi_{1} \\
\vdots \\
\Delta \pi_{15}
\end{array}\right]
$$




\subsection{Total effects on investment, net exports, and inflation}

Next we model the total effects on investment, net exports and inflation integrating both national and cross-country multiplier effects, which is a novelty of this paper.

The total effect on investment determines ultimately the character of the accumulation regime. A strong partial effect of $\pi$ and a weak partial effect of $Y$ on I favour a positive impact of pro-capital redistribution on investment, resulting in a profit-led investment regime $\left(\frac{\Delta I / Y}{\Delta \pi}>0\right)$. In the reverse constellation a pro-capital redistribution would have a negative effect on investment leading to a wage-led investment regime $\left(\frac{\Delta I / Y}{\Delta \pi}<0\right)$. Hence, even if demand is wage-led, investment can be either wage-led or profit-led (Blecker, 2015). The total effects will depend on whether the profitability or the accelerator effects dominate as well as the sign and size of the overall effect of $\pi$ on Y. We calculate the total effects on investment as follows:

$$
\frac{\Delta I / Y}{\Delta \pi}=\left[\left(\frac{\Delta Y / Y}{\Delta \pi} e_{I Y} \frac{I}{Y}\right)+i_{\pi} \frac{I}{R}\right]
$$

where $\frac{\Delta Y / Y}{\Delta \pi}$ illustrates the change in aggregate demand and $e_{I Y}$ reflects the elasticity of investment to GDP. In order to convert elasticities into marginal effects we multiply with the sample mean of $\frac{I}{Y}$. The first term is the ex-post multiplier indirect effect, whereas the second term is the direct partial profitability effect as calculated in equation (3).

Regarding the trade balance, the total effect of a 1\%-point increase in $\pi$ on net exports in wage-led countries will be positive and larger after the multiplier due to a fall in imports following lower growth; however the effect in profit-led countries is theoretically ambiguous. There will be a positive effect on imports due to the rise in GDP in profit-led countries, which partially offsets the positive price competition effects and deteriorates the trade balance position. Furthermore, when there is a simultaneous change in all countries, and if the EU15 as a whole is wage-led, this leads to a decrease in trade partners' GDP, and a negative effect 
on exports. This may offset the positive effects via prices; hence the total effect on trade balance is ambiguous in both the wage-led and profit-led economies. We calculate the postmultiplier net export effects as:

$$
\left[\begin{array}{c}
\frac{\Delta N X / Y_{1}}{\Delta \pi_{1}} \\
\vdots \\
\frac{\Delta N X / Y_{15}}{\Delta \pi_{15}}
\end{array}\right]=\left(N X_{15 \times 15}+P_{15 \times 15}\right)\left[\begin{array}{c}
\Delta \pi_{1} \\
\vdots \\
\Delta \pi_{15}
\end{array}\right]+\left(W_{15 \times 15}-M_{15 \times 15}\right)\left[\begin{array}{c}
\frac{\Delta Y / Y_{1}}{\Delta \pi_{1}} \\
\vdots \\
\frac{\Delta Y / Y_{15}}{\Delta \pi_{15}}
\end{array}\right]
$$

where

$$
\begin{gathered}
N X_{15 \times 15}=\left[\begin{array}{cccc}
\frac{\Delta N X}{Y_{1}} & 0 & \cdots & 0 \\
\Delta \pi_{1} & \ddots & \vdots & \vdots \\
\vdots & \ddots & \ddots & \vdots \\
0 & \cdots & \cdots & \frac{\Delta N X}{Y_{15}} \\
M_{15 \times 15}
\end{array}\right] \\
\left.\qquad \begin{array}{cccc}
\frac{\Delta M_{1}}{\Delta Y_{1}} & 0 & \cdots & 0 \\
0 & \ddots & \cdots & \vdots \\
\vdots & \cdots & \ddots & \vdots \\
0 & \cdots & \cdots & \frac{\Delta M_{15}}{\Delta Y_{15}}
\end{array}\right]
\end{gathered}
$$

where $N X_{i i}=\frac{\frac{\Delta X}{Y_{1}}}{\Delta \pi_{1}}-\frac{\frac{\Delta M}{Y_{1}}}{\Delta \pi_{1}}$ and $M_{i i}=e_{M Y i} \frac{M_{i}}{Y_{i}}$.

Next, we calculate the effect of an isolated change in $\pi$ in one country on inflation $(\Delta \log P)$ as:

$$
\frac{\Delta \log P}{\Delta \pi}=-\left[\frac{\partial \log P}{\partial \log u l c} \frac{\partial \log u l c}{\partial \log r u l c} \frac{\partial \log r u l c}{\partial \log w s}\right] \frac{1}{r u l c}=-\left(e_{P U L C} \frac{1}{1-e_{P U L C}} \frac{Y_{f}}{Y}\right) \frac{1}{r u l c}
$$

The effects of a simultaneous change in $\pi$ on prices in each country is then given by:

$$
\left[\begin{array}{c}
\frac{\Delta \log P}{\Delta \pi_{1}} \\
\vdots \\
\frac{\Delta \log P}{\Delta \pi_{15}}
\end{array}\right]=\left(D P_{15 \times 15}\left[\begin{array}{c}
\Delta \pi_{1} \\
\vdots \\
\Delta \pi_{15}
\end{array}\right]+P M_{15 \times 15}\left[\begin{array}{cccc}
0 & \Delta \pi_{2} & \cdots & \Delta \pi_{15} \\
\Delta \pi_{1} & \ddots & \cdots & \vdots \\
\vdots & \vdots & \ddots & \vdots \\
\Delta \pi_{1} & \Delta \pi_{2} & \cdots & 0
\end{array}\right]\left[\begin{array}{c}
p_{m 1} \\
\vdots \\
p_{m 15}
\end{array}\right]\right)
$$

where 


$$
\begin{gathered}
D P_{15 \times 15}=\left[\begin{array}{cccc}
\frac{\Delta \log P}{\Delta \pi_{1}} & 0 & \cdots & 0 \\
0 & \ddots & \cdots & \vdots \\
\vdots & \vdots & \ddots & \vdots \\
0 & \cdots & \cdots & \frac{\Delta \log P}{\Delta \pi_{15}}
\end{array}\right] \\
P M_{15 \times 15}=\left[\begin{array}{cccc}
0 & \frac{\Delta \log \left(P_{x}\right)_{2}}{\Delta \pi_{2}} \frac{M_{21}}{M_{1}} & \cdots & \frac{\Delta \log \left(P_{x}\right)_{15}}{\Delta \pi_{15}} \frac{M_{151}}{M_{1}} \\
\frac{\Delta \log \left(P_{x}\right)_{1}}{\Delta \pi_{1}} \frac{M_{12}}{M_{2}} & 0 & \cdots & \vdots \\
\vdots & \vdots & \ddots & \vdots \\
\frac{\Delta \log \left(P_{x}\right)_{1}}{\Delta \pi_{1}} \frac{M_{115}}{M_{15}} & \frac{\Delta \log \left(P_{x}\right)_{2}}{\Delta \pi_{2}} \frac{M_{215}}{M_{15}} & \cdots & 0
\end{array}\right]
\end{gathered}
$$

where $D P_{i i}=\frac{\log P}{\Delta \pi}$ and

$$
P M_{i j}=\frac{\Delta \log \left(P_{x}\right)_{j}}{\Delta \pi_{j}} \frac{M_{j i}}{M_{i}}=-\left(e_{P x j} \frac{1}{1-e_{p j}} \frac{Y f_{j}}{Y_{j}} \frac{1}{r u l c_{j}}\right) \frac{M_{j i}}{M_{i}}
$$

$D P$ represents the effects of a change in $\pi$ in country i on domestic prices in country i; $P M_{i j}$ includes the effects of a change in $\pi$ in country $\mathrm{j}$ on inflation in country $\mathrm{i}$ via changes in the import prices of country i.

\section{Estimation methodology}

We apply a single-equation approach in order to analyse the effects of the changes in the wage share on growth for EU15 countries. We estimate the distributional effects on individual components of private aggregate demand, which are consumption, investment, exports and imports for each country as is widely applied in the literature (Stockhammer et al., 2009; Onaran and Galanis, 2014; Hein and Vogel, 2008).

Unit root tests suggest that most of our variables are integrated of order one ${ }^{8}$. Therefore, we take first differences of the variables. The profit share is stationary in Greece, Netherlands, Spain, Sweden and the UK and hence we use this variable in its level in these countries. Error-correction models (ECM) are applied wherever statistically significant ${ }^{9}$.

In all estimations we start with general specifications with both the contemporaneous values and first lags of the variables as well as a lagged dependent variable, and keep those 
variables, which are statistically significant. Wherever there is autocorrelation, either the lagged dependent variable is kept or an AR(1) term is added.

The single equation approach has several advantages. It allows for flexible modelling of the individual behavioural functions for single countries and to detect the precise economic relationships between demand and changes in income distribution (Onaran and Galanis, 2014). Moreover, it is possible to distinguish between domestic and total effects that include international trade. Although it does not explicitly account for the fact that $C, I$ and $N X$ add up to private demand, we do integrate the interactions between the three components of demand indirectly as both investment and imports are functions of domestic GDP, which includes all demand components, and thereby the national multiplier effects are integrated. Moreover, by estimating the Europe wide multiplier effects we incorporate further effects on $C, I$ and $M$.

The main alternative, a vector autoregression model (VAR), estimates the goods market equilibrium in a full model and has been applied by Onaran and Stockhammer (2005) and Stockhammer and Onaran (2004), and Barbosa-Filho and Taylor (2006) among others. The advantage of this approach is that the interaction between the variables can be incorporated and it allows for tracing effects through an entire system rather than analysing one equation at a time. Also, it is more suitable to deal with simultaneity bias. However, using this approach would require a substantial simplification of the model since it cannot handle more than five endogenous variables (Onaran and Galanis, 2014). In the context of our analysis that encompasses seventeen variables, this would lead to a significant misspecification of the behavioural functions and does not give a precise account of the effects of the $w s$ on $C, I$ and $N X$.

The problem is that the VAR structure implies that the lagged values of all variables enter each behavioural function, and it becomes hard to specify each function appropriately or 
issues of overdetermination or misspecification arise; e.g. profit income, wage income, profit share, and nominal unit labour costs would all be allowed to affect import prices. Alternatively, in order to simplify the model a single variable to reflect the wage share would have to be used in all equations; however then the specifications would be misspecified. What we currently do is to introduce the appropriate related variable in each behavioural equation, e.g. profit share in investment, profit and wage incomes in consumption, relative prices in imports, and nominal unit labour costs in price estimations, which we believe are the appropriate behavioural specifications, and this would not be possible in a VAR framework. The estimation regarding the effects on net exports alone requires the stepwise estimation of four separate equations. Simplified direct estimations of net exports as functions of the wage share applied in the former literature (e.g. Bowles and Boyer, 1995; Hein and Vogel, 2007) fail to detect the significant effects of labour costs on foreign demand; hence it is not our preferred approach. In the past decades international trade has increased substantially. As a consequence the estimation of the net export effect is a very sensitive part of the model. Specification of proper behavioural functions is thus a choice we made over the systems estimations.

Furthermore, in a VAR model it is not possible to detect and decompose the precise economic relationships that lead to changes in demand in response to distribution using impulse responses or decomposition analysis, which trace the cumulative effects of changes in all the variables in the system following an initial shock in distribution. The single equation approach has the big advantage that the interpretation of the results is much clearer, which is crucial to understand the mechanisms of how a change in the wage share affects total as well as decomposed parts of aggregate demand. 
The second major qualification relates to changes in the functional income distribution. It is important to recognize that income distribution is endogenous (i.e. a higher unemployment rate lowers the wage share, which usually takes place with a time lag). However, endogenising income distribution, e.g. by using an instrumental variable method, work only if the instrumental variables are valid instruments, and for income distribution the common approach is to use the lags of distribution as instruments, which raises concerns about the validity of the instruments as well as poses challenges regarding the degrees of freedom with short time series data. Using a VAR methodology, in addition to the problems of specification discussed above, also requires identifying some variables as simultaneously exogenous, and the interactions are modelled via the lagged effects only; hence this method also does not offer much more than assuming distribution to be exogenous in the short run and endogenous in the long run. Given these caveats of instrumental variable approaches as well as systems estimations discussed above, in order to focus on the determinants of demand we take the wage share as exogenous in the short run, hence we are implying that the time lag of the effect of output on distribution is longer than one year.

As a result, the convenience of having a clearer interpretation using a single equation approach may come at the price of possible bias due to ignoring the system dimension and endogeneity. The main alternative of using a VAR model approach, however, comes with its own problems.

\section{Estimation Results}

The regression results for consumption are in Table 1 . The hypothesis that the marginal propensity to consume between profit income and wage income differs is confirmed in all countries.

\section{Table 1}


The estimation results for investment are given in Table 2. In all countries, GDP has strong and significant accelerator effects on private investment. The effects of $\pi$ are less robust across countries; it has no statistically significant effect in Austria, Finland, Germany, Greece, Luxembourg, Portugal and the UK. In these cases the effects are treated as zero when we calculate the total effects on private excess demand.

\section{Table 2}

Comparing these results to previous findings in the empirical literature (Onaran and Galanis, 2014; Hein and Vogel, 2008; Stockhammer et al., 2009) we find a general breakdown of the profit-investment nexus since the start of the Great Recession in 2007. Onaran et al. (2011) find that in the case of the US when interest and dividend payments are deducted from the profit share, there is a positive effect on investment illustrating the impact of financialisation on the sensitivity of investment to $\pi$. Such a correction, however, is beyond the scope of this paper due to limited time series data on dividend payments in most EU15 countries.

The estimation results for domestic prices, export prices as well as exports and imports are given in Tables 3 to 6 respectively. The results are in line with our expectations, except in Belgium, Ireland, Luxembourg, Netherlands, and Portugal there are no significant effects of export prices relative to import prices on exports. Similarly, we find no statistically significant effects of domestic prices relative to import prices on imports in the case of Denmark, Finland, Germany, Greece, and Luxembourg. Appendix C summarises the effects of a change in $\pi$ on $X / Y$ and $M / Y$. The total effect does depend not only on the elasticity of exports and imports to relative prices and the pass through from labour costs to prices, but also on the share of the respective component in $\mathrm{GDP}^{10}$. As a result, in small open economies the effects are likely to be much larger compared to large relatively closed economies.

\section{Table 3}




\section{Table 4}

Table 5

Table 6

\subsection{National effects}

Table 7 summarizes the effects of a 1\%-point increase in $\pi$ on components of private aggregate demand: consumption, investment, exports and imports.

The first column reports the partial effects on consumption. The marginal propensity to consume out of wages is higher than out of profits, thus a rise in $\pi$ negatively affects consumption. The differences between marginal propensities to consume range mostly between -0.23 (Ireland) and -0.564 (Greece). However, Belgium, Denmark and Luxembourg have relatively low (-0.15) albeit statistically significant negative consumption differentials ${ }^{11}$.

The second column gives the partial effects on private investment. A 1\%-point increase in $\pi$ in the EU15 countries leads to an increase in investment with values ranging between 0.07\%-points (Netherlands) to $0.20 \%$-points (Belgium) as a ratio to GDP. If we sum up the effects of an increase in $\pi$ on domestic private demand the negative effect on consumption is substantially larger than the positive effect on investment in absolute values in 13 out of 15 countries $^{12}$. Thus, domestic demand in the EU15 is clearly wage-led.

The integration of the foreign sector, however, has a crucial role in determining whether an economy is wage-led or profit-led (Blecker, 1989). The effects of a 1\%-point increase in $\pi$ on net exports range between $0.05 \%$-points (Germany) to $0.40 \%$-points (Austria) as a ratio to GDP.

Column F sums up the partial effects on private excess demand when $\pi$ increases in each country in isolation. Overall, large economies such as the UK, Germany, France, Italy, and Spain as well as some small economies such as Greece, Portugal, Sweden, Finland, 
Netherlands, and Luxemburg are wage-led. Two small economies, Austria and Ireland are profit-led when integrating the foreign sector, as well as Belgium and Denmark, which already had profit-led domestic demand due to low consumption differentials and high investment effects.

Column $\mathrm{G}$ reports the multiplier, which was calculated using the elasticities of $C, I$, and $M$ with regard to $Y$. The multipliers are mostly above one and range between 1.03 in Austria and 2.1 in Spain, with only three small open countries having a multiplier less than one (Belgium, Ireland, Luxembourg, Netherlands) ${ }^{13}$.

When multiplier effects are taken into account, the effect of a change in distribution on demand becomes amplified (for countries with multipliers larger than one). Column $\mathrm{H}$ reports the \%-change in equilibrium aggregate demand after the multiplier mechanism.

\section{Table 7}

The effects of a 1\%-point increase in $\pi$ on investment are diverse as can be seen in Appendix D. Investment regime is wage-led, i.e. the effect of a rise in $\pi$ on $\mathrm{I} / \mathrm{Y}$ is negative in Finland, Germany, Greece, Luxembourg, Portugal, Spain, and the UK whereas the investment regime is profit led in Austria, Belgium, Denmark, France, Ireland, Italy, Netherlands, and Sweden. The effects are ranging from strong negative effects in wage-led countries such as Greece $(-0.43)$ to moderate positive effects in profit-led countries $(0.27)$ such as Denmark.

The effects on the trade balance are almost always positive ranging between 0.07 (Ireland) and 0.32 (Austria). Belgium is an exception with a negative effect due to very low positive net export effects via the price channel and a strong increase in imports following the increase in aggregate demand. The total effects on net exports are larger than the partial effects via price channels in wage-led economies, and lower in profit-led countries (compared to the partial effects reported in Column $\mathrm{E}$ in Table 7). 


\subsection{Europe-wide effects}

Next, we analyse the effects of a simultaneous 1\%-point increase in $\pi$ taking place in all EU15 countries. Column I in Table 7 presents the results. Most strikingly, two economies, which were profit-led in isolation - Austria and Ireland, - also start to contract after the incorporation of further effects on their net exports due to decreasing wage shares of their trade partners, which reduce export prices and GDP of the trade partners, which are wage-led. Thus, when everyone is pursuing the same wage competition strategy in Europe the expansionary effects of an increase in $\pi$ are reversed as relative price effects are moderated and external demand dampens.

Comparing columns $\mathrm{H}$ and $\mathrm{I}$, wage-led economies experience even stronger negative effects on demand. Demand in the large economies (rather closed) such as Germany, France, Spain, Italy and the UK now decrease by $0.23 \%$ to $0.54 \%$. Demand in small open economies such as Ireland, Greece, Austria, Sweden, Finland, and Portugal decrease by values between 0.07\% and 1.03\%. Greece, albeit a small open economy, stands out as a strongly wage-led economy due to very low sensitivity of exports to labour costs ${ }^{14}$, no significant effect of labour costs on imports and no significant effects of profitability on private investment. Even in isolation, a rise in the profit share leads to a $0.92 \%$ fall in demand, and the effect increases further after a race to the bottom in the wage share in Europe. Indeed, only Belgium and Denmark do not contract as an outcome of a simultaneous increase in $\pi$; however, the effects on growth diminish significantly in these countries as well and become almost economically insignificant, close to zero in the case of Belgium.

Overall, a simultaneous decline in the $w s$ in all countries leads to a decline in the EU15 GDP by $0.30 \%$. 
Next, we report the total effects on investment and net exports following a simultaneous 1\%-point increase in $\pi$ in Appendix D Table D.2. In this case 8 countries (including now also Austria) have a wage-led investment regime. The negative effects of a simultaneous rise in $\pi$ on investment are larger (in absolute value) in countries with wage-led investment regimes, and countries with profit-led investment regimes now experience smaller increases in investment due to more moderate growth effects.

Regarding the net exports effects, in all countries, the total effects of a simultaneous rise in $\pi$ is lower (Table D2) compared to the effects of an isolated change in $\pi$ due to the fall in external demand. On average, however, net exports would still increase by $0.16 \%$-points in the EU15 as a whole. Net exports decline only in Belgium.

\subsection{Robustness Checks}

In order to account for the exceptional behaviour of the economies during the crisis years we have checked the robustness of our results using a reduced sample size between 1960 and $2007^{15}$. The results are robust when estimations are repeated excluding the Great Recession years.

As a second robustness check, we used unadjusted wages. We again found that the results are robust.

Third, we also estimated a seemingly unrelated regression model (SUR) to check for the robustness of our results. Indeed, we found cross-correlation among the error terms of all six equations (C, I, P, $\left.P_{x}, X, M\right)$ for the EU15 countries to be statistically significant. This is plausible since the EU15 represent a highly integrated economy, i.e. are affected by a common monetary policy. However, SUR methodology comes at a cost. First, our SUR estimations show that we do not increase statistical significance by applying a systems approach $^{16}$. In contrast, in the investment specifications effects of $\pi$ on investment becomes 
insignificant in the case of France, Spain, and Sweden, as opposed to the significant effects in the single equation estimations. Moreover, there are strong 'contagion effects' within the systems approach; thus a miss-specified equation in one country leads to a change in otherwise significant results in other country specifications. Most importantly, our overall findings remain robust when estimating a SUR model, e.g. the EU15 GDP declines by $0.34 \%$ according to the SUR results, which is very close to the result based on single country simulations and still indicates that Europe as a whole is wage-led.

\section{Comparison with the literature}

In this section we compare our results with the previous empirical research, particularly on the EU MS.

There are two main estimation strategies, accompanied by an ongoing debate about the nature of the demand regime in advanced economies. One strand of literature is motivated by the analysis of a Neo-Kaleckian version of Goodwin's cyclical growth model (e.g. BarbosaFilho and Taylor, 2006; Kiefer and Rada, 2015; Tavani et al., 2011). These studies focus on the systemic linkages between demand and distribution and treat the latter as endogenous. This literature applies a VAR approach to jointly estimate economic activity and distribution ${ }^{17}$. These models estimate a reduced form long run model with short-run cycles typically consisting of only the wage share and capacity utilisation ${ }^{18}$. In alignment with the theoretical assumption that higher profits lead to higher investment, these studies typically find the demand regime to be profit-led. Stockhammer (2015) argues that this literature needs to provide more evidence on the behavioural equations, in particular on the investment function, since it is viewed as the driving force of finding profit-led demand. Furthermore, a series of relevant financial control variables are omitted that might bias the overall findings (Stockhammer, 2015). 
Kiefer and Rada (2015) estimate a VAR with only distribution and growth for a panel of 13 OECD countries including 8 European $\mathrm{MS}^{19}$ and find weak profit-led regimes; however they include a mix of small open and large economies in the panel, which may have quite different structural parameters. Barbosa-Filho and Taylor (2006) find demand to be profit-led but focus exclusively on the US. A notable exception is Stockhammer and Onaran (2004) that estimate a VAR model for France, the UK, and the US and find weak evidence for wage-led demand. Tavani et al. (2011), confirm previous results of a profit-led regime in the US but a wage-led regime in Netherlands. Jump and Mendieta-Munoz (2015) test the wage-led demand hypothesis for the UK using a structural VAR approach and find evidence in favour of a wage-led demand regime.

A larger group of papers apply a single equation approach estimating behavioural functions for consumption, investment and the external sector separately. These studies use annual data and usually interpret the effects as a partial goods market equilibrium with a focus on the medium run (Stockhammer, 2015).

In this group, our results are in alignment with those of Onaran and Galanis (2014), Storm and Naastepad (2012), Stockhammer et al. (2011), Stockhammer and Ederer (2008) for Austria, Finland, Germany, France, Italy, Netherlands, Spain, Sweden and the UK.

Storm and Naastepad (2012) find Denmark to be wage-led in domestic demand as well as total demand and Belgium to be undefined. However, their estimations do not pay attention to unit root issues. Furthermore, international trade is modelled by means of estimating the effects of real unit labour costs directly on exports, and they do not estimate the effects on imports.

Bowles and Boyer (1995) find profit-led regimes in total demand in Germany and France. However, while their paper is seminal in terms of testing strategy, they do not discuss the 
time series properties of their variables and hence do not apply difference or error correction models.

Stockhammer and Stehrer (2011), focusing on domestic demand only, find mixed results for Ireland, depending on the amount of lags included. However, they find perverse but statistically insignificant consumption effects. In alignment with our findings, the authors find domestic demand in Luxembourg to be wage-led.

Hein and Vogel (2008) differ from our results regarding the Netherlands only, which they find to be profit-led. However, the unconventional finding that domestic demand is profit-led drives these results.

Hartwig (2014) finds that demand in the OECD is slightly wage-led based on panel data estimations for single components of demand. Stockhammer and Wildauer (2015) also apply panel data estimations for single equations and find demand in 18 OECD countries on average to be wage-led ${ }^{20}$.

Overall, our results confirm the findings of the majority of studies that domestic demand tends to be wage-led; aggregate demand in large economies also tend to be wage-led, whereas small open economies may be profit-led due to international trade effects.

To the best of our knowledge, this paper is the first to estimate the aggregate demand regime in Greece, Portugal, Ireland and Luxembourg.

While the results of single country versus panel data estimations are not comparable, it is worth noting that single equation and VAR estimation strategies have yielded contradicting results in some cases, mostly for the case of the US, and although the US is not the focus of this paper, the differences in methodologies may need further explanation ${ }^{21}$.

Blecker (2015) emphasizes that studies, which have found profit-led economies using a VAR approach, have used methodologies that focus on short-run cyclical relationships ${ }^{22}$. The diversity of findings across the single equation estimation studies might be explained by the 
fact that, depending on the specifications in the econometric model, they pick up short-run as well as long-run relationships ${ }^{23}$.

The argument to pay attention to the time dimension of the effects has some merit since both studies that find profit-led demand regimes, Barbosa-Filho and Taylor (2006) for the US, and Kiefer and Rada (2015) for a panel, analyse short-run cyclical dynamics. Moreover, as Stockhammer and Stehrer (2011) show, the estimated effects on domestic demand are quite sensitive to the lag length in separate time series equations for 12 OECD countries. With regards to the study by Barbosa-Filho and Taylor (2006), Stockhammer and Stehrer (2011) point out that the econometric results might suffer from autocorrelation problems. Moreover, they found the results to be very sensitive to the lag length. Increasing the lag length (two to four lags using quarterly data) turns the original finding of a profit-led regime into a wage-led one. In addition, the empirical findings for the consumption function (negative effects of an increase in the wage share on consumption) in Barbosa-Filho and Taylor (2006) are perverse.

To summarize, there are single equation based as well as systems based estimations, which deliver similar results regarding the wage-led nature of the demand regime in several European countries (e.g. Stockhammer and Onaran, 2004 or Jump and Mendieta-Munoz, 2015) and the differences between findings in the case of the US seem to be driven by the treatment of auto-correlation and lag length issues.

In another attempt to address the potential reasons behind the profit-led finding in the Goodwin's cyclical growth model, Stockhammer and Michell (2014) demonstrate theoretically that in a simple Minsky model extended by a reserve army distribution adjustment mechanism, the wage share responds positively to output but generates no feedback. Instead, cycles are generated through the interaction of financial fragility and demand with the latter not being influenced by changes in functional income distribution. 
This holds true even if a wage-led demand regime is introduced to the model by allowing for a positive feedback effect from the wage share to output. Hence, finding a counter-clockwise motion in output-wage-share space might not be enough evidence to rule out the possibility of a wage-led demand regime.

As a result, empirical studies based on Goodwin cycle models that do not control for debt variables might base their findings of profit-led demand on spurious correlations (Blecker, 2015; Stockhammer, 2015).

However, our paper, as most other studies using the single equation approach, also omits debt variables due to lack of long time series data for each EU15 country. A notable exception is Stockhammer and Wildauer (2015) who control for effects of personal income distribution, asset prices and debt. Also, Onaran et al. (2011) integrate housing and financial wealth effects on consumption and find the US to be a moderately wage-led demand regime.

Detached from the literature on wage-led and profit-led demand regimes a study by the IMF (Decressin et al., 2015) has simulated a 2\% wage moderation scenario in a coherent multi-country model including five European countries (Greece, Italy, Ireland, Portugal, and Spain), to discuss the short run economic impact on output. Following an exogenous 2\% reduction in wages in all Euro area economies over two years, Euro area GDP declines by 1\% below its level and inflation decreases by $2 \%$ points, given that monetary policy is constrained by the zero lower bound. The paper thus confirms one of our core results: A simultaneous decline in the wage share in all EU15 countries eliminates the positive competitiveness effects on net exports.

\section{Wage-led recovery scenarios}

In this section, we set out the effects of an alternative scenario of a simultaneous wage-led recovery in the EU15 countries over the next 5 years on growth, investment, net exports and 
inflation. Obviously, if all countries increase their wage share by 1\%-point EU15 GDP would go up by $0.30 \%{ }^{24}$. In this scenario, however, the small open economies Belgium and Denmark would contract. In table 8, we illustrate an alternative scenario that takes into account country specific room for manoeuvre to increase the wage share.

In this scenario, all EU15 countries follow a differentiated increase in the wage share with a 5\%-point increase in the wage-led countries, a 3\%-point increase in the intermediate group of Ireland and Austria, which become wage-led in the race to the bottom scenario, and a 1\%point increase in Belgium and Denmark, which remain profit-led also in the race to the bottom scenario. In this scenario, all EU15 countries can grow along with an improvement in the ws leading to an increase in EU15 GDP of 1.51\%. Hence, there is an empirical case for wage-coordination to stimulate growth with equality in Europe.

\section{Table 8}

The effects on investment are shown in column C. In 9 European countries the positive accelerator effects overpower the negative profitability effects leading to a wage-led investment regime. Greece experiences the strongest positive effects on $I / Y$ of roughly $2.4 \%$ points. We find a profit-led investment regime in only six cases (Belgium, France, Ireland, Italy, Netherlands and Sweden). While further investment policies are undoubtedly required, particularly in countries with profit-led investment regimes, overall a wage-led recovery could generate an increase of $0.24 \%$-points in $I / Y$ in the EU15.

The effects on net exports are negative in the majority of the EU15 except Belgium and Denmark as can be seen in column D. While net exports/GDP decrease by only $0.05 \%$-points in Ireland, it decreases by $1.40 \%$-points in Greece. Again further industrial policy is required to address trade imbalances.

Finally, we analyse to what extent a wage stimulus in the EU15 countries would exert inflationary pressures. 
On average, annual inflation would rise by $1.4 \%$-point as an outcome of a simultaneous $1 \%$ point increase in the wage share in the EU15 countries, and 1.2\%-point following a differentiated increase in the wage share as suggested in alternative our scenario, as reported in Appendix D Table D3. The effects on inflation are not as strong as the effects on nominal ulc since firms might not be able translate higher costs into higher prices, particularly in relatively open economies ${ }^{25}$. As an outcome of our wage-led recovery scenario, the majority of countries would experience increasing inflation rates well below the ECB target inflation rate (2\%). In light of a risk of deflation in the Eurozone our findings indicate that a wage stimulus in the EU15 would indeed help keeping the European economy away from deflation.

Labour factor productivity in the EU15 countries increased by roughly $0.7 \%$ in the decade between 1997 and 2007 on average excluding the crisis years. Our alternative scenario would be consistent with an annual nominal wage increase of 3.1\% in the EU15 on average (e.g. $1.9 \%$ in Ireland, 3.6\% in Greece).

\section{Conclusion}

The empirical analysis in this paper shows that a simultaneous decline in the wage share in a highly integrated European economy leads to a decline in growth. Hence there is room to stimulate demand in the current economic climate of deficient demand and sluggish growth: A 1\%-point simultaneous increase in the wage share at the European level could lead to a 0.30\% increase in EU15 GDP.

The negative effects of a fall in the wage share on consumption overpower the positive effects on investment in 13 European countries. Domestic demand is hence clearly wage-led in the EU15. Some small open economies may have a profit-led regime when the foreign sector is included due to a higher degree of openness of the economy, whereas the net export 
effects tend not to dominate in relatively closed large economies. In isolation, we have found 11 countries to be wage-led and 4 countries to be profit-led.

This paper went beyond the nation state and estimated the impact of a simultaneous decline in the wage share on demand and hence growth in EU15 countries. In the case of a simultaneous fall in the wage share, the positive net export effects are essentially wiped out leaving profit-led demand regimes in only two countries (Belgium and Denmark). Thus, when all EU15 countries pursue beggar thy neighbour policies, the competitiveness effects will be minor, while the domestic effects dominate. Reversing these policies would promote growth, albeit the effects are economically not large. A cautious interpretation of the empirical results would suggest a more equal income distribution does not hamper growth in Europe.

The results also illustrate a fallacy of composition. Even if increasing profit shares seem to promote growth at the national level in some profit-led economies, at the European level a simultaneous fall in the wage share leads to European demand deficiency as well as contraction, even in originally profit-led economies such as Austria and Ireland.

The estimated model in this paper has been kept simple to analyse the role of income distribution in determining private demand. Possible extensions include a richer modelling of the government sector, i.e. the potential crowding in effects on private investment.

The applied estimation approach might introduce some bias resulting from endogeneity issues and single-equation-based estimations. However, our results are robust across different sample sizes, and estimation methods (i.e. the use of SUR) and in alignment with the findings of the majority of previous studies for single countries. Moreover, our result that the EU15 in aggregate is wage-led is plausible against the background that the EU15 countries have low extra regional trade and hence represent a rather closed economy, and the domestic demand regime (consumption + private investment) in the EU15 is wage-led, which is a very robust 
finding - in our study as well as in the literature on other countries. Our results, in line with previous literature, clearly show that the negative effects of a fall in the wage share on domestic consumption outweigh the expansionary effects on investment in the vast majority of the countries. Additionally, a simultaneous decline in the wage share in all EU15 countries eliminates most positive net exports effects among the trade partners in Europe. As a consequence the finding that the EU15 is wage-led in aggregate is in line with intuition.

Policies of internal devaluation have been negative for demand and growth in the EU15. In an alternative scenario of a wage-led recovery, we have shown that it is possible for all countries to grow along a simultaneous differentiated increase in the wage share. If large wage-led economies take the initiative, egalitarian growth becomes feasible including in small open economies. A recovery led by domestic demand and an increase in the wage share would help to restore workers' purchasing power and tackle the issue of reliance on private debt to support consumption, particularly in the periphery of Europe. In countries such as Greece, a wage-led recovery would also increase tax revenues and contribute to a reduction in public debt/GDP ratio. Indeed debt sustainability would require structural reforms to increase the minimum wages, reinstate collective bargaining institutions, and increase public sector pay with an aim to increase the wage share as opposed to further deregulation in the labour market and wage cuts as suggested by the IMF and the EC in Greece.

Furthermore, a wage-led recovery would still be consistent with annual inflation rates well below the ECB target. A coordinated wage stimulus is what is needed currently to keep Europe away from deflation.

An increase in the wage share, interestingly, does not negatively impact the investment performance in the EU15 as a whole with most countries experiencing an increase in investment. The impact of wage increases on trade imbalances across countries require 
further targeted industrial policy at the European level. Achieving convergence in the level of nominal unit labour costs and overcoming persistent imbalances requires a more comprehensive policy mix of wage policies, investment and industrial policies.

Our results have important policy implications. First, if a country is wage-led, increasing the wage share is not an impediment to growth. Second, wage policy coordination in a highly integrated Europe, which tends to be wage-led, can improve growth. Third, a coordinated wage stimulus does not have negative effects on investment in aggregate and induced inflation does not conflict with the ECB target. Finally, a wage-led recovery scenario as an alternative to the current strategy of wage moderation implemented in the European countries is feasible, given that the coordination problem can be overcome. 


\section{References}

Atkinson, A.B. 2009. Factor shares: the principal problem of political economy? Oxford Review of Economic Policy, 25(1):3-16

Banerjee, A., Dolado, J.J. and Mestre, R. 1998. Error-correction Mechanism Tests for Cointegration in a Single-equation Framework, Journal of Time Series Analysis, 19(3):267-283

Barbosa-Filho, N. H. \& Taylor, L. 2006. Distributive and Demand Cycles in the US economy - A Structuralist Goodwin Model. Metroeconomica, 57(3):389-411

Bhaduri, A. and Marglin, S. 1990. Unemployment and the real wage - The EconomicBasis for contesting political ideologies, Cambridge Journal of Economics, 14(4):375-393

Blanchard, O. 2006. Macroeconomics, 4 ed., New York, Prentice Hall

Blecker, R.A. 1989. International competition, Income Distribution and Economic Growth, Cambridge Journal of Economics, 13(3):395-412

Blecker, R.A. 2015. Wage-led versus profit-led demand regimes: The long and the short of it, Eastern Economics Association Conference, New York, February

Bowles, S. and Boyer, R. 1995. Wages, aggregate demand, and employment in an open economy: an empirical investigation. In: Epstein, G.A. and Gintis, H. (eds.). Macroeconomic policy after the conservative era, Cambridge, Cambridge University Press

Daudey, E. and Garcia-Penalosa, C. 2007. The personal and the factor distributions of income in a cross-section of countries, Journal of Development Studies, 43(5):812-829

Decressin, J., Espinoza, R. A., Halikias, I., Leigh, D., Loungani, P., Medas, P. A., Mursula, S.,

Schindler, M., Spilimbergo, A. and Xu, T. 2015. Wage Moderation in Crises: Policy Considerations and Applications to the Euro Area, Staff Discussion Notes No. 15/22, Washington, D.C., International Monetary Fund

EC 2011. Annual Growth Survey, http://ec.europa.eu/europe2020/making-it-happen/annual-growthsurveys/2012/index_en.htm [last accessed 02 April 2015]

EC 2012. Annual Growth Survey, http://ec.europa.eu/europe2020/making-it-happen/annual-growthsurveys/2012/index_en.htm [last accessed 03 April 2015]

EC 2013. Labour Costs Pass-through, Profits and Rebalancing in Vulnerable Member States, Quarterly Report on the Euro Area, 12(3), http://ec.europa.eu/economy_finance/publications/qr_euro_area/2013/qrea3_en.htm [last accessed 01 April 2015]

Eurostat 2015. Intra-EU27 trade, by Member State, total product, http://ec.europa.eu/eurostat/tgm/table.do?tab=tableandinit=1andlanguage=enandpcode=tet00039a ndplugin=1 [last accessed 01. March 2015]

Hartwig, J. 2014. Testing the Bhaduri-Marglin model with OECD panel data, International Review of Applied Economics, 28(4):419-435

Hein, E. and Vogel, L. 2008. Distribution and growth reconsidered: empirical results for six OECD Countries, Cambridge Journal of Economics, 32(3):479-511

IMF, 2009. Global Economic Policies and Prospects, Meeting of the Ministers and Central Bank Governors, March 13-14, London, UK, https://www.imf.org/external/np/g20/pdf/031909a.pdf [last accessed 02 February 2015]

Jump. R, and Mendieta-Munoz, I., 2015. Wage Led Aggregate Demand in the United Kingdom, 19th Conference of the Research Network Macroeconomics and Macroeconomic Policies (FMM), The Spectre of Stagnation? Europe in the World Economy, Berlin, October

Kiefer, D. \& Rada, C. 2015. Profit maximising goes global: the race to the bottom. Cambridge Journal of Economics, 39(5):1333-1350

Lagoa, S., Leao, E., Mamede, R. and Barradas, R. 2014. Report on the financial system in Portugal, FESSUD studies, http://EconPapers.repec.org/RePEc:fes:fstudy:fstudy09 [last accessed 01 February 2015] 
Lavoie, M. and Stockhammer, E. 2013. Wage-led growth: Concept, theories and policies, Basingstoke, UK, Palgrave Macmillan and International Labour Organisation

Marglin, S.A. and Bhaduri, A. 1992. Profit Squeeze and Keynesian Theory. In: Marglin, S.A. and Schor, J.B. (eds.). The Golden Age of Capitalism: Reinterpreting the Postwar Experience, Oxford, Oxford University Press

Naastepad, C.W. and Storm, S. 2006. OECD demand regimes (1960-2000), Journal of Post Keynesian Economics, 29(2):211-246

Onaran, O. and Galanis, G. 2014. Income distribution and growth: a global model, Environment and Planning A, 46(10):2489-2513

Onaran, O. and Stockhammer, E. 2005. Two different export-oriented growth strategies Accumulation and distribution in Turkey and South Korea, Emerging Markets Finance and Trade, 41(1):65-89

Onaran, O., Stockhammer, E. and Grafl, L. 2011. Financialisation, income distribution and aggregate demand in the USA, Cambridge Journal of Economics, 35(4):637-661

Rezai, A. 2011. The political economy implications of general equilibrium analysis in open economy macro models, Working Paper 11/2011, Department of Economics, New School for Social Research, http://www.economicpolicyresearch.org/econ/2011/NSSR_WP_112011.pdf [last accessed 07 January 2015]

Stockhammer, E. and Ederer, S. 2008. Demand effects of the falling wage share in Austria, Empirica, 35(5):481-502

Stockhammer, E. and Onaran, O. 2004. Accumulation, distribution and employment: a structural VAR approach to a Kaleckian macro model, Structural Change and Economic Dynamics, 15(4):421-447

Stockhammer,E., Hein, E. and Grafl, L. 2011. Globalization and the effects of changes in functional income distribution on aggregate demand in Germany, International Review of Applied Economics, 25(1):1-23

Stockhammer, E., Onaran, O. and Ederer, S. 2009. Functional income distribution and aggregate demand in the Euro area, Cambridge Journal of Economics, vol. 33, no.1, 139-159

Stockhammer, E. and Stehrer, R. 2011. Goodwin or Kalecki in Demand? Functional Income Distribution and Aggregate Demand in the Short Run, Review of Radical Political Economics, vol. 43(4):506-522

Stockhammer, E. \& Michell, J. 2014. Pseudo-Goodwin cycles in a Minsky model, Post Keynesian Economics Study Group Working Paper 1405, http://econpapers.repec.org/paper/pkewpaper/pkwp1405.htm [last accessed 01 July 2015]

Stockhammer, E. \& Wildauer, R. 2015. Debt-driven growth? Wealth, distribution and demand in OECD countries. Cambridge Journal of Economics, forthcoming

Stockhammer 2015. Wage-led versus profit-led demand: what have we learned? A Kalecki-Minsky view. Review of Keynesian Economics special edition, forthcoming

Storm, S. and Naastepad, C.W.M. 2012. Macroeconomics Beyond the NAIRU, Cambridge, Massachusetts, Harvard University Press

Tavani, D., Flaschel, P. \& Taylor, L. 2011. Estimated non-linearities and multiple equilibria in a model of distributive-demand cycles. International Review of Applied Economics, 25(5):519-538

Von Arnim, R., Tavani, D. and Barbosa de Carvalho, L. 2012. Globalization as coordination failure: a Keynesian perspective, Working Paper 02/2012, Department of Economics, New School for Social Research, http://www.boeckler.de/pdf/v_2012_10_25_tavani_von_arnim_de_carvalho.pdf [last accessed 01 March 2015] 


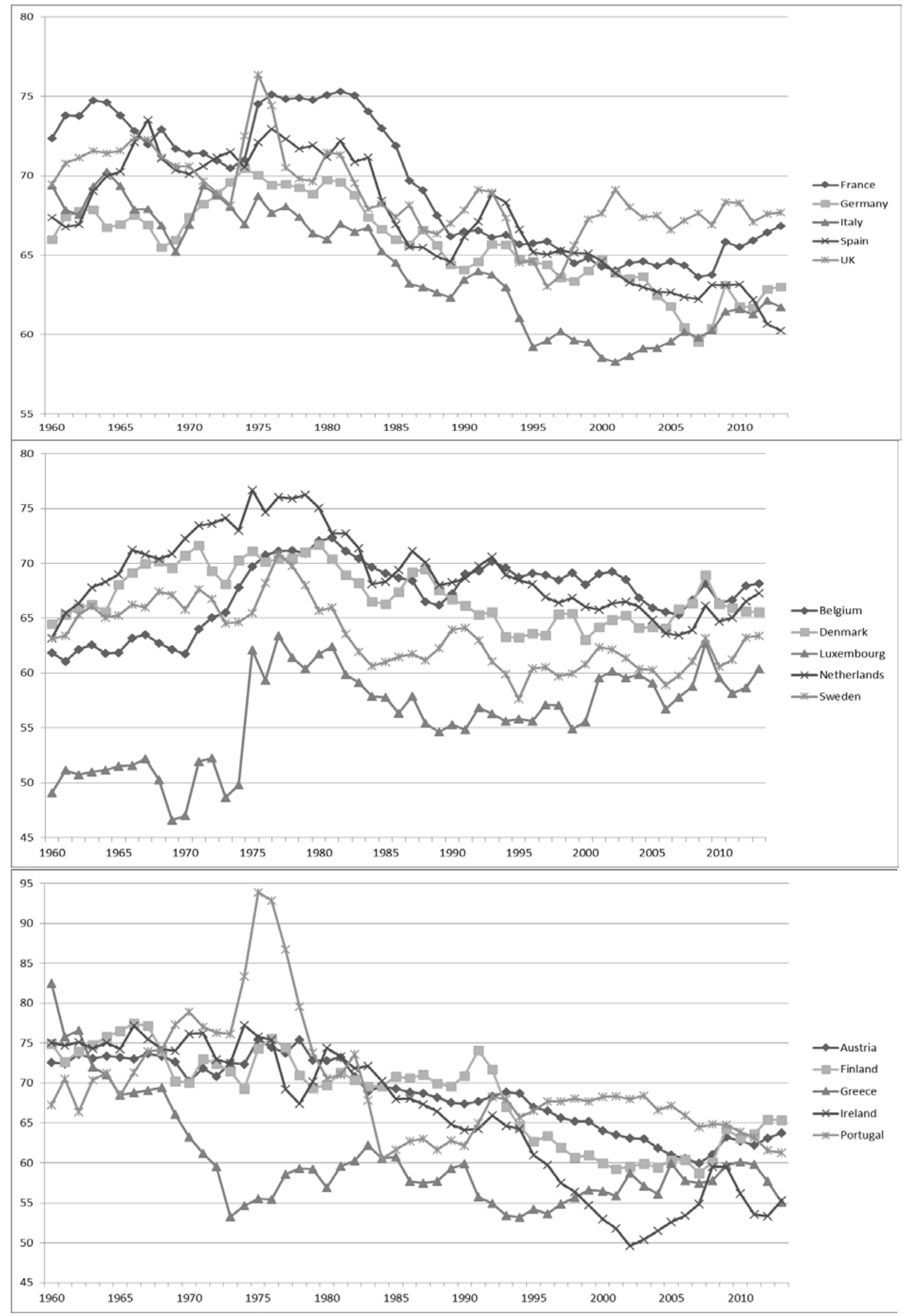

Fig. 1. Wage Share (adjusted, ratio to GDP at factor cost, \%). Source: AMECO online. 
Table 1. Consumption: dependent variable dlog(C)

\begin{tabular}{|c|c|c|c|c|c|c|c|c|}
\hline & $\boldsymbol{c}$ & $\operatorname{dlog}\left(R_{t}\right)$ & $\operatorname{dlog}\left(W_{t}\right)$ & $\operatorname{dlog}\left(C_{t}-1\right)$ & $(A R \mathbf{1})$ & $D W$ & $R 2$ & Sample \\
\hline \multirow[t]{2}{*}{$\overline{\mathbf{A}}$} & 0.005 & 0.160 & 0.616 & & & 2.369 & 0.527 & 1961-2013 \\
\hline & (1.567) & $(4.394) * * *$ & $(6.024) * * *$ & & & & & \\
\hline \multirow[t]{2}{*}{ B } & 0.007 & 0.148 & 0.483 & & & 2.241 & 0.590 & 1961-2013 \\
\hline & $(2.963) * * *$ & $(3.832) * * *$ & $(7.506) * * *$ & & & & & \\
\hline \multirow[t]{2}{*}{ DK } & 0.001 & 0.236 & 0.655 & & & 1.869 & 0.564 & $1961-2013$ \\
\hline & $(0.323)$ & $(4.758) * * *$ & $(6.262) * * *$ & & & & & \\
\hline \multirow[t]{2}{*}{ FIN } & 0.007 & 0.184 & 0.635 & & & 1.694 & 0.774 & $1961-2013$ \\
\hline & $(2.735) * * *$ & $(7.984) * * *$ & $(11.061) * * *$ & & & & & \\
\hline \multirow[t]{2}{*}{$\mathbf{F}$} & 0.006 & 0.143 & 0.657 & & & 2.074 & 0.771 & 1961-2013 \\
\hline & $(2.751) * * *$ & $(4.865) * * *$ & $(10.635) * * *$ & & & & & \\
\hline \multirow[t]{2}{*}{$\mathbf{D}$} & 0.004 & 0.101 & 0.476 & 0.292 & & 2.090 & 0.707 & $1962-2013$ \\
\hline & (1.313) & $(2.151) * * *$ & (4.352).*** & $(2.500) * *$ & & & & \\
\hline \multirow[t]{2}{*}{ GR } & 0.013 & 0.114 & 0.633 & & & 1.771 & 0.748 & 1961-2013 \\
\hline & (3.889) *** & $(3.859) * * *$ & $(10.282) * * *$ & & & & & \\
\hline \multirow[t]{2}{*}{ IRL } & 0.004 & 0.183 & 0.520 & & & 2.233 & 0.483 & 1961-2013 \\
\hline & $(0.798)$ & $(4.746) * * *$ & $(5.153) * * *$ & & & & & \\
\hline \multirow[t]{2}{*}{$\mathbf{I}$} & 0.004 & 0.204 & 0.744 & & & 1.531 & 0.773 & 1961-2013 \\
\hline & $(1.793) *$ & $(4.713) * * *$ & $(9.447) * * *$ & & & & & \\
\hline \multirow[t]{2}{*}{$\mathbf{L}$} & 0.016 & 0.103 & 0.350 & & & 1.741 & 0.350 & $1961-2013$ \\
\hline & $(4.087) * * *$ & $(3.451) * * *$ & $(4.920) * * *$ & & & & & \\
\hline \multirow[t]{2}{*}{ NL } & -0.004 & 0.149 & 0.582 & 0.376 & & 1.876 & 0.813 & $1962-2013$ \\
\hline & $-(1.574)$ & $(4.807) * * *$ & $(5.749) * * *$ & $(3.766) * * *$ & & & & \\
\hline \multirow[t]{2}{*}{$\mathbf{P}$} & 0.012 & 0.099 & 0.612 & & & 2.121 & 0.615 & 1961-2013 \\
\hline & $(3.025) * * *$ & $(6.177) * * *$ & $(8.195) * * *$ & & & & & \\
\hline \multirow[t]{2}{*}{$\mathbf{E}$} & 0.001 & 0.182 & 0.767 & & & 2.096 & 0.878 & 1961-2013 \\
\hline & $(0.278)$ & $(4.750) * * *$ & $(16.751) * * *$ & & & & & \\
\hline \multirow[t]{2}{*}{$\mathbf{S}$} & 0.006 & 0.088 & 0.554 & & & 1.736 & 0.578 & 1961-2013 \\
\hline & $(2.279) * *$ & $(2.788) * * *$ & $(7.891) * * *$ & & & & & \\
\hline \multirow[t]{2}{*}{ UK } & 0.005 & 0.209 & 0.702 & & 0.273 & 1.944 & 0.718 & $1962-2013$ \\
\hline & (1.627) & $(6.744) * * *$ & $(7.567) * * *$ & & $(1.884) *$ & & & \\
\hline
\end{tabular}

$\mathrm{NL}=$ Netherlands, $\mathrm{P}=$ Portugal, $\mathrm{E}=$ Spain, $\mathrm{S}=$ Sweden, $\mathrm{UK}=$ United Kingdom 
Table 2. Private investment: dependent variable dlog(I)

\begin{tabular}{|c|c|c|c|c|c|c|c|c|c|c|c|c|c|}
\hline & $c$ & $\operatorname{dlog}\left(\pi_{t}-1\right)$ & $\log \left(\pi_{t}-1\right)$ & $\operatorname{dlog}\left(Y_{t}\right)$ & $\operatorname{dlog}\left(I_{t}-1\right)$ & $\operatorname{dlog}\left(r_{t}-1\right)$ & $d \log r_{t}$ & $\log \left(I_{t}-1\right)$ & $\log \left(Y_{t}-1\right)$ & $(A R 1)$ & $D W$ & $R 2$ & Sample \\
\hline \multirow[t]{2}{*}{$\mathbf{A}$} & -0.025 & 0.110 & & 1.881 & & & & & & & 2.018 & 0.526 & $1962-2013$ \\
\hline & $-(2.828) * * *$ & $(0.830)$ & & (7.359) *** & & & & & & & & & \\
\hline \multirow[t]{2}{*}{ B } & -0.632 & & 0.239 & 2.387 & 0.234 & & & -0.247 & 0.330 & & 1.932 & 0.638 & 1963-2013 \\
\hline & $-(4.595) * * *$ & & $(2.290) * *$ & $(6.527) * * *$ & $(2.340) * *$ & & & $-(4.107) * * *$ & $(4.789) * * *$ & & & & \\
\hline \multirow[t]{2}{*}{ DK } & -0.038 & 0.321 & & 2.929 & & -0.008 & & & & & 1.883 & 0.751 & 1963-2013 \\
\hline & $-(4.448) * * *$ & $(1.948) *$ & & $(11.168) * * *$ & & $-(2.310) * *$ & & & & & & & \\
\hline \multirow[t]{2}{*}{ FIN } & -0.038 & 0.174 & & 2.067 & & & & & & 0.322 & 1.841 & 0.752 & 1963-2013 \\
\hline & $-(3.451) * * *$ & (1.588) & & $(9.138) * * *$ & & & & & & $(2.186) * *$ & & & \\
\hline \multirow[t]{2}{*}{$\mathbf{F}$} & -0.032 & 0.155 & & 2.214 & & & -0.002 & & & 0.541 & 1.940 & 0.826 & 1963-2013 \\
\hline & $-(4.221) * * *$ & $(1.646) *$ & & $(12.179) * * *$ & & & $-(1.300)$ & & & $(4.616) * * *$ & & & \\
\hline \multirow[t]{2}{*}{ D } & -0.021 & 0.121 & & 1.810 & & & & & & 0.360 & 1.613 & 0.590 & 1963-2013 \\
\hline & $-(2.196) * *$ & $(0.544)$ & & $(7.149) . * * *$ & & & & & & $(2.154) * *$ & & & \\
\hline \multirow[t]{2}{*}{ GR } & 0.028 & & 0.091 & 2.293 & & & & & & -0.265 & 2.017 & 0.625 & $1962-2013$ \\
\hline & $(0.513)$ & & (1.518) & $(9.862) * * *$ & & & & & & $-(1.907) *$ & & & \\
\hline \multirow[t]{2}{*}{ IRL } & -0.036 & 0.338 & & 1.802 & & & & & & & 1.988 & 0.416 & 1963-2013 \\
\hline & $-(1.976) *$ & $(1.967) *$ & & $(5.004) * * *$ & & & & & & & & & \\
\hline \multirow[t]{2}{*}{ I } & -0.026 & 0.295 & & 1.722 & & -0.003 & & & & 0.331 & 1.944 & 0.636 & 1964-2013 \\
\hline & $-(2.941) * * *$ & $(1.761) *$ & & $(7.841) * * *$ & & $-(1.172)$ & & & & $(2.293) * *$ & & & \\
\hline \multirow[t]{2}{*}{$\mathbf{L}$} & -0.029 & 0.160 & & 1.728 & & & & & & & 2.410 & 0.273 & 1963-2013 \\
\hline & $-(1.420)$ & $(0.675)$ & & $(4.172) * * *$ & & & & & & & & & \\
\hline \multirow[t]{2}{*}{ NL } & -0.392 & & 0.130 & 2.681 & & & & -0.299 & 0.295 & & 2.299 & 0.714 & $1961-2013$ \\
\hline & $-(2.762) * * *$ & & (3.030) *** & $(9.527) * * *$ & & & & $-(5.346) * * *$ & $(5.237) * * *$ & & & & \\
\hline \multirow[t]{2}{*}{$\mathbf{P}$} & -0.042 & 0.024 & & 2.119 & & & & & & & 2.026 & 0.485 & $1962-2013$ \\
\hline & $-(2.834) * * *$ & $(0.440)$ & & $(6.662) * * *$ & & & & & & & & & \\
\hline \multirow[t]{2}{*}{$\mathbf{E}$} & 0.099 & & 0.134 & 2.720 & & & & & & 0.415 & 1.994 & 0.769 & $1962-2013$ \\
\hline & (1.098) & & $(1.664) *$ & $(9.443) * * *$ & & & & & & $(3.297) * * *$ & & & \\
\hline \multirow[t]{2}{*}{$S$} & 0.119 & & 0.159 & 2.406 & 0.269 & & & & & & 1.794 & 0.729 & $1962-2013$ \\
\hline & $(1.759) *$ & & $(2.384) * *$ & (9.892) *** & $(3.437) * * *$ & & & & & & & & \\
\hline \multirow[t]{2}{*}{ UK } & -0.474 & & 0.134 & 2.283 & & & & -0.243 & 0.261 & & 1.909 & 0.677 & $1961-2013$ \\
\hline & $-(1.815) *$ & & $(1.581)$ & $(8.870) * * *$ & & & & $-(3.527) * * *$ & $(3.220) * * *$ & & & & \\
\hline
\end{tabular}


Table 3. Price deflator: dependent variable dlog $(P)$

\begin{tabular}{|c|c|c|c|c|c|c|c|c|c|c|}
\hline & $\boldsymbol{c}$ & $\operatorname{dlog}\left(U L C_{t}-1\right)$ & $\operatorname{dlog} U L C_{t}$ & $\operatorname{dlog}\left(P_{t}-1\right)$ & $\operatorname{dlog}\left(\operatorname{Pm}_{t}\right)$ & $\operatorname{dlog}\left(\mathrm{Pm}_{t}-1\right)$ & $(A R 1)$ & $D W$ & $R 2$ & Sample \\
\hline A & $\begin{array}{c}0.005 \\
(2.433) * *\end{array}$ & & $\begin{array}{c}0.286 \\
(4.952) * * *\end{array}$ & $\begin{array}{c}0.453 \\
(5.320) * * *\end{array}$ & $\begin{array}{c}0.146 \\
(3.715) * * *\end{array}$ & & & 1.920 & 0.851 & $1962-2012$ \\
\hline B & $\begin{array}{c}0.020 \\
(3.797) * * *\end{array}$ & $\begin{array}{c}0.180 \\
(2.226) * *\end{array}$ & & & $\begin{array}{c}0.154 \\
(5.036) * * *\end{array}$ & $\begin{array}{c}0.129 \\
(4.333) * * *\end{array}$ & $\begin{array}{c}0.627 \\
(4.829) * * *\end{array}$ & 2.163 & 0.811 & 1962-2012 \\
\hline DK & $\begin{array}{c}0.008 \\
(2.423) * *\end{array}$ & $\begin{array}{c}0.249 \\
(2.698) * * *\end{array}$ & & $\begin{array}{c}0.465 \\
(4.037) * * *\end{array}$ & & $\begin{array}{c}0.183 \\
(5.266) * * *\end{array}$ & & 2.029 & 0.865 & 1962-2012 \\
\hline FIN & $\begin{array}{c}0.009 \\
(2.511) * *\end{array}$ & & $\begin{array}{c}0.388 \\
(5.328) * * *\end{array}$ & $\begin{array}{c}0.249 \\
(2.834) * * *\end{array}$ & $\begin{array}{c}0.220 \\
(5.520) * * *\end{array}$ & & & 1.890 & 0.842 & 1962-2012 \\
\hline $\mathbf{F}$ & $\begin{array}{c}0.004 \\
(1.718) *\end{array}$ & $\begin{array}{r}0.194 \\
(1.624)\end{array}$ & & $\begin{array}{c}0.633 \\
(4.635) * * *\end{array}$ & & $\begin{array}{c}0.094 \\
(3.580) * * *\end{array}$ & & 1.795 & 0.907 & $1962-2012$ \\
\hline D & $\begin{array}{c}0.017 \\
(4.333) * * *\end{array}$ & & $\begin{array}{c}0.382 \\
(7.351) * * *\end{array}$ & & $\begin{array}{r}0.006 \\
(0.290)\end{array}$ & & $\begin{array}{c}0.699 \\
(6.577) * * *\end{array}$ & 2.091 & 0.834 & $1962-2012$ \\
\hline GR & $\begin{array}{c}0.019 \\
(2.870) * * *\end{array}$ & $\begin{array}{c}0.423 \\
(5.932) * * *\end{array}$ & & & $\begin{array}{c}0.462 \\
(6.435) * * *\end{array}$ & & & 1.758 & 0.810 & 1962-2012 \\
\hline IRL & $\begin{array}{c}0.031 \\
(2.987) * * *\end{array}$ & $\begin{array}{c}0.256 \\
(1.863) *\end{array}$ & & & $\begin{array}{c}0.284 \\
(3.744) * * *\end{array}$ & & $\begin{array}{c}0.431 \\
(2.490) * *\end{array}$ & 2.111 & 0.678 & 1962-2012 \\
\hline I & $\begin{array}{c}0.014 \\
(3.033) * * *\end{array}$ & $\begin{array}{c}0.633 \\
(10.044) * * *\end{array}$ & & & $\begin{array}{c}0.206 \\
(5.279) * * *\end{array}$ & & & 1.715 & 0.828 & 1962-2012 \\
\hline $\mathbf{L}$ & $\begin{array}{c}0.024 \\
(4.180) * * *\end{array}$ & & $\begin{array}{c}0.345 \\
(3.284) * * *\end{array}$ & $\begin{array}{c}-0.482 \\
-(3.605) * * *\end{array}$ & $\begin{array}{c}0.523 \\
(5.076) * * *\end{array}$ & & & 1.715 & 0.479 & 1962-2012 \\
\hline NL & $\begin{array}{c}0.007 \\
(2.492) * *\end{array}$ & $\begin{array}{c}0.255 \\
(2.687) * * *\end{array}$ & & $\begin{array}{c}0.448 \\
(3.656) * * *\end{array}$ & & $\begin{array}{c}0.152 \\
(4.599) * * *\end{array}$ & & 1.997 & 0.801 & 1962-2012 \\
\hline $\mathbf{P}$ & $\begin{array}{c}0.018 \\
(3.200) * * *\end{array}$ & $\begin{array}{c}0.471 \\
(7.345) * * *\end{array}$ & & & $\begin{array}{c}0.204 \\
(4.035) * * *\end{array}$ & $\begin{array}{c}0.247 \\
(4.491) * * *\end{array}$ & & 1.803 & 0.857 & 1962-2012 \\
\hline $\mathbf{E}$ & $\begin{array}{c}0.029 \\
(2.904) * * *\end{array}$ & & $\begin{array}{c}0.585 \\
(8.027) * * *\end{array}$ & & $\begin{array}{r}0.023 \\
(1.093)\end{array}$ & & $\begin{array}{c}0.798 \\
(8.667) * * *\end{array}$ & 2.284 & 0.937 & 1962-2012 \\
\hline $\mathbf{S}$ & $\begin{array}{c}0.016 \\
(2.914) * * *\end{array}$ & $\begin{array}{c}0.342 \\
(4.107) * * *\end{array}$ & & & $\begin{array}{c}0.151 \\
(3.926) * * *\end{array}$ & $\begin{array}{c}0.220 \\
(5.499) * * *\end{array}$ & $\begin{array}{c}0.359 \\
(2.154) * *\end{array}$ & 1.951 & 0.817 & 1962-2012 \\
\hline UK & $\begin{array}{c}0.016 \\
(2.968) * * *\end{array}$ & $\begin{array}{c}0.582 \\
(7.530) * * *\end{array}$ & & & $\begin{array}{c}0.184 \\
(3.048) * * *\end{array}$ & & & 1.715 & 0.695 & $1962-2012$ \\
\hline
\end{tabular}

Notes: A = Austria, B = Belgium, DK = Denmark, FIN = Finland, F = France, D = Germany, GR = Greece, IRL = Ireland, I = Italy, L = Luxembourg, NL =

Netherlands, $\mathrm{P}=$ Portugal, $\mathrm{E}=$ Spain, $\mathrm{S}=$ Sweden, $\mathrm{UK}=$ United Kingdom 
Table 4. Export price deflator: dependent variable dlog(Px)

\begin{tabular}{|c|c|c|c|c|c|c|c|c|c|c|c|c|c|}
\hline & $c$ & $\begin{array}{c}d \operatorname{dlog} \\
\left(U L C_{t}-1\right)\end{array}$ & $\begin{array}{c}d \log \\
\left(U L C_{t}\right)\end{array}$ & $\begin{array}{c}d l o g \\
\left(P X_{t}-1\right) \\
\end{array}$ & $\begin{array}{l}\text { dlog } \\
\left(\mathrm{Pm}_{t}\right) \\
\end{array}$ & $\begin{array}{c}\text { dlog } \\
\left(\mathrm{Pm}_{t}-1\right)\end{array}$ & $\begin{array}{c}\log \\
\left(P X_{t}-1\right)\end{array}$ & $\begin{array}{c}\log \\
\left(U L C_{t}-1\right)\end{array}$ & $\begin{array}{c}\log \\
\left(\mathrm{Pm}_{t^{-1}}\right)\end{array}$ & $(A R \mathbf{R})$ & $D W$ & $R 2$ & Sample \\
\hline \multirow[t]{2}{*}{$\mathbf{A}$} & 0.002 & & 0.152 & & 0.616 & & & & & & 2.339 & 0.867 & $1961-2013$ \\
\hline & $(1.060)$ & & $(3.490) * * *$ & & $(15.385) * * *$ & & & & & & & & \\
\hline \multirow[t]{2}{*}{ B } & 0.001 & & 0.096 & & 0.789 & & & & & & 2.037 & 0.949 & $1961-2013$ \\
\hline & $(0.674)$ & & $(1.920) *$ & & $(26.133) * * *$ & & & & & & & & \\
\hline \multirow[t]{2}{*}{ DK } & 1.307 & & 0.085 & & 0.687 & & -0.643 & 0.223 & 0.385 & & 2.045 & 0.916 & $1961-2013$ \\
\hline & $(4.828) * * *$ & & $(1.031)$ & & $(15.211) * * *$ & & $-(4.950) * * *$ & $(4.748) * * *$ & $(4.642) * * *$ & & & & \\
\hline \multirow[t]{2}{*}{ FIN } & -0.003 & & 0.185 & & 0.776 & & & & & & 1.569 & 0.879 & 1961-2013 \\
\hline & $-(0.811)$ & & $(2.612) * * *$ & & $(15.279) * * *$ & & & & & & & & \\
\hline \multirow[t]{2}{*}{$\mathbf{F}$} & -0.002 & 0.248 & & 0.142 & 0.528 & & & & & & 1.875 & 0.956 & $1962-2013$ \\
\hline & $-(1.025)$ & $(4.124) * * *$ & & $(3.074) * * *$ & $(21.465) * * *$ & & & & & & & & \\
\hline \multirow[t]{2}{*}{ D } & 0.004 & 0.197 & & 0.224 & 0.365 & & & & & & 1.667 & 0.823 & $1962-2013$ \\
\hline & $(1.653) *$ & $(3.122) * * *$ & & $(3.227) * * *$ & $(11.266) * * *$ & & & & & & & & \\
\hline \multirow[t]{2}{*}{ GR } & 1.115 & & 0.154 & & 0.828 & & -0.511 & 0.192 & 0.297 & & 1.880 & 0.914 & $1961-2013$ \\
\hline & $(3.237) * * *$ & & (1.631) & & $(12.355) * * *$ & & $-(4.341) * * *$ & $(3.250) * * *$ & $(3.536) * * *$ & & & & \\
\hline \multirow[t]{2}{*}{ IRL } & 0.000 & & 0.171 & & 0.708 & & & & & & 2.004 & 0.810 & 1961-2013 \\
\hline & $(0.009)$ & & $(1.946) *$ & & $(10.398) * * *$ & & & & & & & & \\
\hline \multirow[t]{2}{*}{ I } & 0.000 & 0.185 & & 0.539 & 0.210 & & & & & -0.315 & 1.980 & 0.950 & $1963-2013$ \\
\hline & $(0.113)$ & (3.179) *** & & $(19.040) * * *$ & $(3.630) * * *$ & & & & & $-(2.029) * *$ & & & \\
\hline \multirow[t]{2}{*}{$\mathbf{L}$} & 0.024 & & 0.322 & & & -0.001 & & & & & 1.800 & 0.076 & $1962-2013$ \\
\hline & $(2.389) * *$ & & $(1.704) *$ & & & $-(0.006)$ & & & & & & & \\
\hline \multirow[t]{2}{*}{ NL } & 0.002 & 0.370 & & & & 0.229 & & & & & 2.008 & 0.171 & $1962-2013$ \\
\hline & $(0.251)$ & $(1.823) *$ & & & & $(1.877) *$ & & & & & & & \\
\hline \multirow[t]{2}{*}{$\mathbf{P}$} & 0.280 & -0.103 & & 0.246 & 0.722 & -0.251 & -0.382 & 0.053 & 0.330 & & 1.834 & 0.930 & $1962-2013$ \\
\hline & $(1.786) *$ & $-(1.658) *$ & & $(1.845) *$ & $(14.862) * * *$ & $-(2.301) * *$ & $-(4.404) * * *$ & $(1.971) * *$ & $(5.082) * * *$ & & & & \\
\hline \multirow[t]{2}{*}{$\mathbf{E}$} & 0.012 & 0.255 & & 0.155 & 0.421 & & & & & 0.461 & 1.744 & 0.870 & 1963-2013 \\
\hline & (1.483) & $(2.507) * *$ & & $(1.716) *$ & $(11.016) * * *$ & & & & & $(3.076) * * *$ & & & \\
\hline \multirow[t]{2}{*}{$\mathbf{S}$} & -0.002 & & 0.172 & & 0.716 & & & & & & 1.928 & 0.877 & $1961-2013$ \\
\hline & $-(0.616)$ & & $(2.509) * *$ & & $(16.126) * * *$ & & & & & & & & \\
\hline \multirow[t]{2}{*}{ UK } & 0.558 & & 0.136 & & 0.577 & & -0.486 & 0.101 & 0.377 & & 1.667 & 0.928 & 1961-2013 \\
\hline & $(3.051) * * *$ & & $(2.084) * *$ & & $(13.998) * * *$ & & $-(4.725) * * *$ & $(3.172) * * *$ & $(4.975) * * *$ & & & & \\
\hline
\end{tabular}

Notes: $\mathrm{A}=$ Austria, $\mathrm{B}=$ Belgium, DK = Denmark, FIN = Finland, $\mathrm{F}=$ France, $\mathrm{D}=$ Germany, GR = Greece, IRL = Ireland, $\mathrm{I}=\mathrm{Italy}, \mathrm{L}=\mathrm{Luxembourg}, \mathrm{NL}=\mathrm{Netherlands,} \mathrm{P} \mathrm{=}$

Portugal, $\mathrm{E}=$ Spain, $\mathrm{S}=$ Sweden, $\mathrm{UK}=$ United Kingdom 
Table 5. Exports: dependent variable $d \log (X)$

\begin{tabular}{|c|c|c|c|c|c|c|c|c|c|}
\hline & $\boldsymbol{c}$ & $\left.\operatorname{dlog}(P x / P m)_{t-1}\right)$ & $\operatorname{dlog}(P x / P m)_{t}$ & $\operatorname{dlog}\left(Y_{r w_{t}}\right)$ & $\operatorname{dlog}\left(e_{t}\right)$ & $(A R \mathbf{1})$ & $D W$ & $R 2$ & Sample \\
\hline \multirow[t]{2}{*}{$\bar{A}$} & -0.028 & & -1.728 & 2.314 & & & 1.778 & 0.676 & $1961-2013$ \\
\hline & $-(2.813) * * *$ & & $-(5.717) * * *$ & $(9.008) * * *$ & & & & & \\
\hline \multirow[t]{2}{*}{$\mathbf{B}$} & -0.029 & & -0.185 & 2.315 & & & 1.876 & 0.669 & 1961-2013 \\
\hline & $-(3.264) * * *$ & & $-(0.728)$ & $(10.045) * * *$ & & & & & \\
\hline \multirow[t]{2}{*}{ DK } & -0.004 & & -0.627 & 1.540 & & & 1.718 & 0.472 & $1961-2013$ \\
\hline & $-(0.483)$ & & $-(3.581) * * *$ & $(6.445) * * *$ & & & & & \\
\hline \multirow[t]{2}{*}{ FIN } & -0.068 & & -0.576 & 3.428 & & 0.430 & 2.121 & 0.486 & 1962-2013 \\
\hline & $-(3.074) * * *$ & & $-(2.003) * *$ & $(6.415) * * *$ & & $(3.077) * * *$ & & & \\
\hline \multirow[t]{2}{*}{$\mathbf{F}$} & -0.020 & & -0.439 & 2.155 & 0.158 & 0.371 & 2.194 & 0.725 & $1962-2013$ \\
\hline & $-(1.718) *$ & & $-(3.075) * * *$ & $(7.689) * * *$ & $(1.665) *$ & $(2.684) * * *$ & & & \\
\hline \multirow[t]{2}{*}{$\mathbf{D}$} & -0.017 & -0.379 & & 2.136 & & & 2.022 & 0.372 & $1962-2013$ \\
\hline & $-(1.145)$ & $-(1.876) *$ & & $(5.376) * * *$ & & & & & \\
\hline \multirow[t]{2}{*}{ GR } & -0.037 & -0.729 & & 2.917 & & & 1.664 & 0.305 & $1962-2013$ \\
\hline & $-(1.342)$ & $-(1.805) *$ & & $(3.968) * * *$ & & & & & \\
\hline \multirow[t]{2}{*}{ IRL } & 0.043 & & -0.178 & 1.041 & & 0.351 & 1.896 & 0.189 & $1962-2013$ \\
\hline & $(2.223) * *$ & & $-(0.903)$ & $(2.155) * *$ & & $(2.608) * * *$ & & & \\
\hline \multirow[t]{2}{*}{$\mathbf{I}$} & -0.053 & -0.307 & & 3.006 & & & 1.966 & 0.586 & $1962-2013$ \\
\hline & $-(3.811) * * *$ & $-(1.994) * *$ & & $(8.285) * * *$ & & & & & \\
\hline \multirow[t]{2}{*}{$\mathbf{L}$} & -0.033 & 0.187 & & 2.688 & & 0.317 & 2.102 & 0.388 & 1963-2013 \\
\hline & $-(1.621)$ & (0.789) & & $(4.893) * * *$ & & $(2.064) * *$ & & & \\
\hline \multirow[t]{2}{*}{ NL } & -0.027 & & -0.290 & 2.445 & & 0.559 & 2.194 & 0.725 & 1962-2013 \\
\hline & $-(2.681) * * *$ & & $-(1.318)$ & $(10.955) * * *$ & & $(4.761) * * *$ & & & \\
\hline \multirow[t]{2}{*}{$\mathbf{P}$} & -0.017 & 0.316 & & 2.409 & & 0.330 & 1.816 & 0.420 & 1963-2013 \\
\hline & $-(0.799)$ & (1.354) & & $(4.401) * * *$ & & $(2.383) * *$ & & & \\
\hline \multirow[t]{2}{*}{$\mathbf{E}$} & -0.012 & & -0.277 & 2.448 & & & 1.664 & 0.426 & 1961-2013 \\
\hline & $-(0.815)$ & & $-(2.214) * *$ & $(6.029) * * *$ & & & & & \\
\hline \multirow[t]{2}{*}{$\mathbf{S}$} & -0.045 & & -0.508 & 2.715 & & 0.497 & 2.037 & 0.575 & $1962-2013$ \\
\hline & $-(3.009) * * *$ & & $-(2.915) * * *$ & $(7.877) * * *$ & & $(3.832) * * *$ & & & \\
\hline \multirow[t]{2}{*}{ UK } & 0.001 & & -0.518 & 1.174 & & & 1.562 & 0.453 & 1961-2013 \\
\hline & $(0.152)$ & & $-(3.708) * * *$ & $(4.696) * * *$ & & & & & \\
\hline
\end{tabular}

Notes: A = Austria, B = Belgium, DK = Denmark, FIN = Finland, F = France, D = Germany, GR = Greece, IRL = Ireland, I = Italy, L = Luxembourg, $\mathrm{NL}=$ Netherlands, $\mathrm{P}=$ Portugal, $\mathrm{E}=$ Spain, $\mathrm{S}=$ Sweden, $\mathrm{UK}=$ United Kingdom 
Table 6. Imports: dependent variable dlog(M)

\begin{tabular}{|c|c|c|c|c|c|c|c|c|c|c|c|c|c|}
\hline & $c$ & $\begin{array}{c}\text { dlog } \\
\left.(P / P m)_{t}-1\right)\end{array}$ & $\begin{array}{c}\text { dlog } \\
(\mathrm{P} / \mathrm{Pm})_{t}\end{array}$ & $\begin{array}{c}\text { dlog } \\
\left(Y_{t}\right)\end{array}$ & $\begin{array}{c}\text { dlog } \\
\left(Y_{t}-1\right)\end{array}$ & $\begin{array}{c}d l o g \\
\left(m_{t}-1\right)\end{array}$ & $\begin{array}{c}\log \\
\left(m_{t}-1\right)\end{array}$ & $\begin{array}{c}\log \\
\left(P / P m_{t}-1\right)\end{array}$ & $\begin{array}{c}\log \\
\left(Y_{t}-1\right)\end{array}$ & $(A R 1)$ & DW & $R 2$ & Sample \\
\hline \multirow[t]{2}{*}{ A } & -0.005 & 0.329 & & 1.970 & & & & & & & 2.251 & 0.648 & $1962-2013$ \\
\hline & $-(0.701)$ & $(1.786) *$ & & $(8.114) * * *$ & & & & & & & & & \\
\hline \multirow[t]{2}{*}{ B } & 0.004 & 0.336 & & 1.649 & & & & & & -0.272 & 2.131 & 0.692 & 1963-2013 \\
\hline & $(0.668)$ & $(3.790) * * *$ & & $(8.360) * * *$ & & & & & & $-(1.917) *$ & & & \\
\hline \multirow[t]{2}{*}{ DK } & 0.006 & & -0.152 & 1.868 & & & & & & & 2.004 & 0.618 & 1961-2013 \\
\hline & $(0.907)$ & & $-(1.272)$ & $(8.994) * * *$ & & & & & & & & & \\
\hline \multirow[t]{2}{*}{ FIN } & -0.007 & & -0.115 & 1.854 & & & & & & & 2.082 & 0.677 & 1961-2013 \\
\hline & $-(0.886)$ & & $-(0.946)$ & $(10.137)^{* * *}$ & & & & & & & & & \\
\hline \multirow[t]{2}{*}{$\mathbf{F}$} & -0.001 & 0.296 & & 1.940 & & & & & & & 2.008 & 0.725 & $1962-2013$ \\
\hline & $-(0.159)$ & $(3.604) * * *$ & & $(8.884) * * *$ & & & & & & & & & \\
\hline \multirow[t]{2}{*}{ D } & 0.007 & & 0.101 & 2.010 & & & & & & 0.241 & 1.918 & 0.684 & $1963-2013$ \\
\hline & $(0.923)$ & & (1.098) & $(9.666) * * *$ & & & & & & $(1.728) *$ & & & \\
\hline \multirow[t]{2}{*}{ GR } & 0.019 & & 0.148 & 1.268 & & & & & & & 1.767 & 0.510 & $1961-2013$ \\
\hline & $(1.830) *$ & & $(0.772)$ & $(6.884) * * *$ & & & & & & & & & \\
\hline \multirow[t]{2}{*}{ IRL } & -1.578 & & 0.174 & 1.351 & & 0.230 & -0.527 & 0.163 & 0.807 & & 2.091 & 0.559 & $1962-2013$ \\
\hline & $-(3.623) * * *$ & & (1.417) & $(5.249) * * *$ & & $(1.839)$ * & $-(4.032) * * *$ & $(1.941)^{*}$ & (3.909) *** & & & & \\
\hline \multirow[t]{2}{*}{ I } & 0.000 & 0.195 & & 2.829 & -0.858 & & & & & & 2.032 & 0.719 & $1962-2013$ \\
\hline & $-(0.010)$ & $(2.236) * *$ & & $(10.797)^{* * *}$ & $-(3.394) * * *$ & & & & & & & & \\
\hline \multirow[t]{2}{*}{$\mathbf{L}$} & 0.010 & & -0.025 & 1.230 & & & & & & & 2.146 & 0.490 & $1961-2013$ \\
\hline & (1.107) & & $-(0.168)$ & $(6.925) * * *$ & & & & & & & & & \\
\hline \multirow[t]{2}{*}{ NL } & 0.007 & 0.145 & & 1.589 & & & & & & & 1.873 & 0.727 & $1962-2013$ \\
\hline & (1.341) & $(1.930) *$ & & $(9.536) * * *$ & & & & & & & & & \\
\hline \multirow[t]{2}{*}{$\mathbf{P}$} & -2.121 & & 0.340 & 1.641 & & & -0.555 & 0.411 & 0.858 & & 1.636 & 0.551 & $1961-2013$ \\
\hline & $-(3.979) * * *$ & & $(2.408) * *$ & $(5.161) * * *$ & & & $-(4.128) * * *$ & $(3.773) * * *$ & $(4.141) * * *$ & & & & \\
\hline \multirow[t]{2}{*}{$\mathbf{E}$} & -0.009 & 0.225 & & 2.443 & & & & & & & 1.581 & 0.649 & $1962-2013$ \\
\hline & $-(0.769)$ & $(2.073) * *$ & & $(8.171) * * *$ & & & & & & & & & \\
\hline \multirow[t]{2}{*}{ S } & -0.009 & 0.252 & & 2.063 & & & & & & & 2.210 & 0.678 & $1962-2013$ \\
\hline & $-(1.317)$ & $(2.808) * * *$ & & $(9.993) * * *$ & & & & & & & & & \\
\hline \multirow[t]{2}{*}{ UK } & -4.300 & & -0.010 & 1.778 & & & -0.594 & 0.098 & 1.083 & & 2.114 & 0.798 & 1961-2013 \\
\hline & $-(5.583) * * *$ & & $-(0.184)$ & $(11.126) * * *$ & & & $-(5.721) * * *$ & $(2.633) * * *$ & $(5.677) * * *$ & & & & \\
\hline
\end{tabular}


Table 7. The effects of a 1\%-point increase in the profit share

\section{The effect of a 1\%-point increase in the profit share in only one country on:}

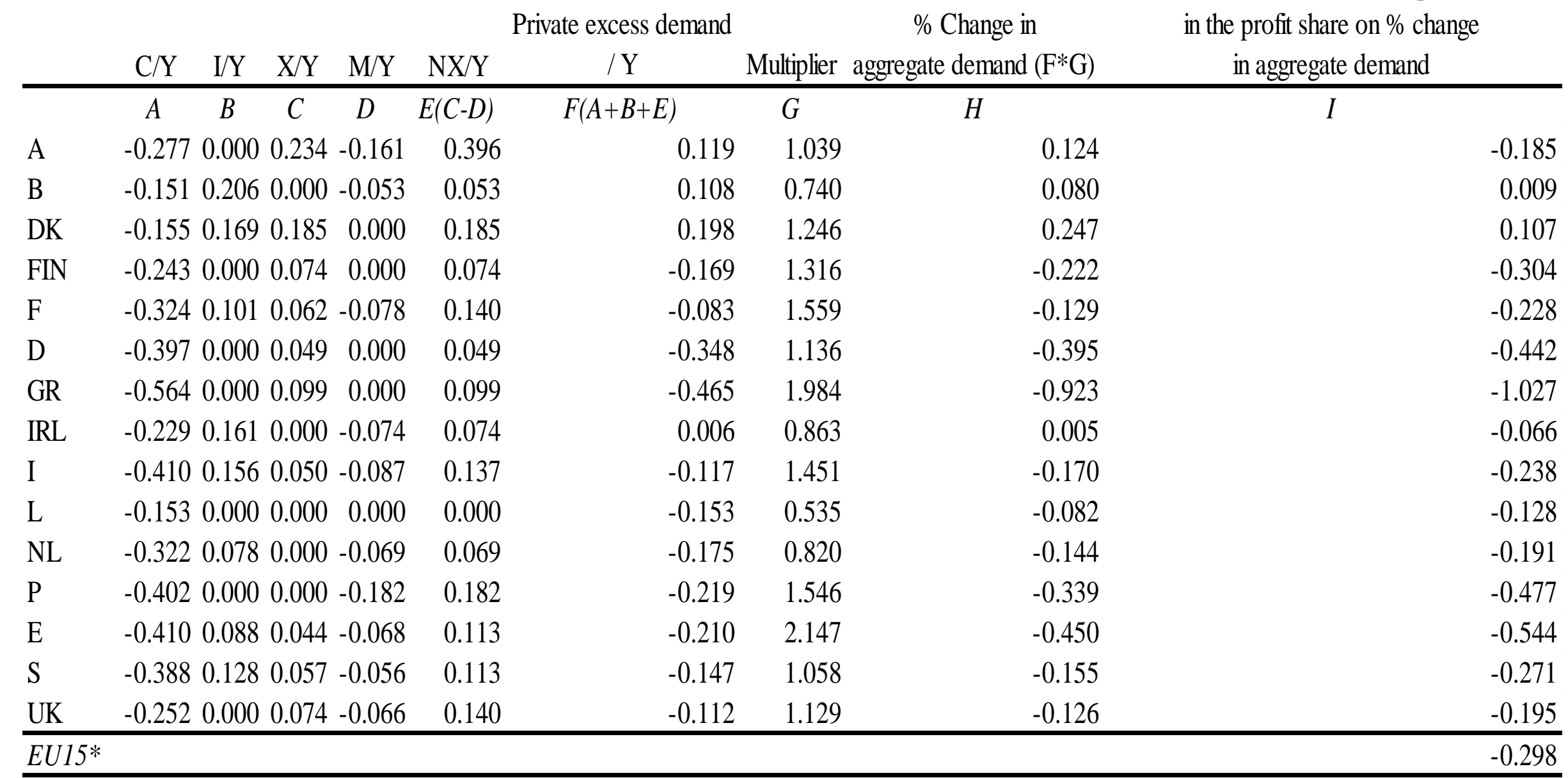

Notes: A = Austria, B = Belgium, DK = Denmark, FIN = Finland, F = France, D = Germany, GR = Greece, IRL = Ireland, I = Italy, L = Luxembourg, NL = Netherlands,

$\mathrm{P}=$ Portugal, $\mathrm{E}=$ Spain, $\mathrm{S}=$ Sweden, $\mathrm{UK}=$ United Kingdom

* Change in each country is multiplied by its share in EU15 GDP. 
Table 8. The effects of a differentiated increase in the wage share on growth, investment and net exports

\begin{tabular}{|c|c|c|c|c|c|c|}
\hline & $\begin{array}{l}\text { Change in } \\
\text { profit share }\end{array}$ & & mand & & Total effect on I/Y & Total effect on NX/Y \\
\hline & A & & $B$ & & $C$ & $D$ \\
\hline A & & -3.00 & & 1.147 & 0.431 & -0.419 \\
\hline B & & -1.00 & & 0.269 & -0.138 & 0.202 \\
\hline DK & & -1.00 & & 0.443 & 0.020 & 0.153 \\
\hline FIN & & -5.00 & & 1.489 & 0.647 & -0.758 \\
\hline $\mathrm{F}$ & & -5.00 & & 1.120 & -0.053 & -0.753 \\
\hline $\mathrm{D}$ & & -5.00 & & 2.195 & 0.684 & -0.913 \\
\hline GR & & -5.00 & & 5.123 & 2.358 & -1.404 \\
\hline IRL & & -3.00 & & 0.332 & -0.379 & -0.052 \\
\hline I & & -5.00 & & 1.181 & -0.409 & -0.842 \\
\hline $\mathrm{L}$ & & -5.00 & & 0.641 & 0.167 & -0.355 \\
\hline NL & & -5.00 & & 0.953 & -0.225 & -0.641 \\
\hline $\mathrm{P}$ & & -5.00 & & 2.375 & 0.895 & -1.004 \\
\hline $\mathrm{E}$ & & -5.00 & & 2.713 & 1.024 & -1.303 \\
\hline S & & -5.00 & & 1.275 & -0.095 & -0.812 \\
\hline UK & & -5.00 & & 0.959 & 0.144 & -0.756 \\
\hline EU15* & & & & 1.511 & 0.245 & -0.794 \\
\hline
\end{tabular}

Notes: A = Austria, B = Belgium, DK = Denmark, FIN = Finland, F = France, D = Germany, GR = Greece, IRL = Ireland, I = Italy, L = Luxembourg, NL = Netherlands, $\mathrm{P}=$ Portugal, $\mathrm{E}=$ Spain, $\mathrm{S}=$ Sweden, $\mathrm{UK}=$ United Kingdom

* Change in each country is multiplied by its share in EU15 GDP. 
Appendix A - Data Sources

\begin{tabular}{|c|c|c|c|}
\hline $\begin{array}{l}\text { Time-series } \\
\text { data }\end{array}$ & Variable & Definition & $\begin{array}{l}\text { Source } \\
\text { [Variable construction] }\end{array}$ \\
\hline $\begin{array}{l}\text { Adjusted wage } \\
\text { share }\end{array}$ & ws & $\begin{array}{l}\text { Compensation per } \\
\text { employee as percentage of } \\
\text { GDP at factor cost per } \\
\text { person employed }\end{array}$ & $\begin{array}{l}\text { AMECO Database } \\
\text { http://ec.europa.eu/ }\end{array}$ \\
\hline $\begin{array}{l}\text { Adjusted profit } \\
\text { share }\end{array}$ & $\pi$ & & {$[\pi=1-w s]$} \\
\hline $\begin{array}{l}\text { GDP in market } \\
\text { prices } \\
\text { (real) }\end{array}$ & $Y$ & $\begin{array}{l}\text { Gross domestic product at } \\
2010 \text { market prices }\end{array}$ & AMECO Database \\
\hline $\begin{array}{l}\text { GDP at factor } \\
\text { costs } \\
\text { (real) }\end{array}$ & $Y_{f}$ & $\begin{array}{l}\text { Gross domestic product at } \\
\text { market prices minus toxes } \\
\text { on production and } \\
\text { imports, plus subsidies }\end{array}$ & AMECO Database \\
\hline $\begin{array}{l}\text { Private } \\
\text { Consumption } \\
\text { (real) }\end{array}$ & c & $\begin{array}{l}\text { Private final consumption } \\
\text { expenditure at constant } \\
\text { prices }\end{array}$ & AMECO Database \\
\hline $\begin{array}{l}\text { Adjusted } \\
\text { compensation } \\
\text { of employees } \\
\text { (real) }\end{array}$ & $W$ & & {$\left[W=w s * Y_{f}\right]$} \\
\hline $\begin{array}{l}\text { Adjusted gross } \\
\text { operating surplus } \\
\text { (real) }\end{array}$ & $R$ & & {$\left[R=\pi * Y_{f}\right]$} \\
\hline $\begin{array}{l}\text { Total Investment } \\
\text { (real) }\end{array}$ & $I_{t}$ & $\begin{array}{l}\text { Gross fixed capital } \\
\text { formation at constant } \\
\text { prices; total economy }\end{array}$ & AMECO Database \\
\hline $\begin{array}{l}\text { Total investment } \\
\text { (current prices) }\end{array}$ & $I_{\text {teurt }}$ & $\begin{array}{l}\text { Gross foxed capital } \\
\text { formation at current } \\
\text { prices; total economy }\end{array}$ & AMECO Database \\
\hline $\begin{array}{l}\text { Private } \\
\text { investment } \\
\text { (current prices) }\end{array}$ & $I_{p r}$ & $\begin{array}{l}\text { Gross fixed capital } \\
\text { formation at current } \\
\text { prices; private sector }\end{array}$ & AMECO Database \\
\hline $\begin{array}{l}\text { Ratio of private } \\
\text { to } \\
\text { total investment }\end{array}$ & $I_{p s}$ & & {$\left[I_{p s}=I_{p r} / I_{\text {tcurr }}\right]$} \\
\hline $\begin{array}{l}\text { Private } \\
\text { Investment } \\
\text { (real) }\end{array}$ & I & & {$\left[I=I_{t} * I_{p s}\right]$} \\
\hline $\begin{array}{l}\text { Real long-term } \\
\text { interest rate }\end{array}$ & $r$ & $\begin{array}{l}\text { Real long-term interest } \\
\text { rates, deflator GDP }\end{array}$ & AMECO Database \\
\hline GDP Deflator & $P$ & $\begin{array}{l}\text { Price deflator gross } \\
\text { domestic product at market } \\
\text { prices }\end{array}$ & AMECO Database \\
\hline $\begin{array}{l}\text { Import price } \\
\text { deflator }\end{array}$ & $P_{m}$ & $\begin{array}{l}\text { Price deflator imports of } \\
\text { goods and } \\
\text { services }\end{array}$ & AMECO Database \\
\hline
\end{tabular}




\begin{tabular}{|c|c|c|c|}
\hline $\begin{array}{l}\text { Export price } \\
\text { deflator }\end{array}$ & $P_{x}$ & $\begin{array}{l}\text { Price deflator exports of } \\
\text { goods and } \\
\text { services }\end{array}$ & AMECO Database \\
\hline $\begin{array}{l}\text { Exports } \\
\text { (real) }\end{array}$ & $X$ & $\begin{array}{l}\text { Exports of goods and } \\
\text { services at } \\
\text { constant prices }\end{array}$ & AMECO Database \\
\hline $\begin{array}{l}\text { Imports } \\
\text { (real) }\end{array}$ & $M$ & $\begin{array}{l}\text { Imports of goods and } \\
\text { services at constant prices }\end{array}$ & AMECO Database \\
\hline $\begin{array}{l}\text { Foreign GDP } \\
\text { (real) }\end{array}$ & $Y_{r w}$ & $\begin{array}{l}\text { GDP of the rest of the } \\
\text { world }\end{array}$ & $\begin{array}{l}\text { World Bank World } \\
\text { Development Indicators } \\
\text { (WDI) } \\
\text { http://data.worldbank.org } \\
\text { [World GDP (in constant } \\
2005 \text { US\$) - own GDP (in } \\
\text { constant 2005 USS)] }\end{array}$ \\
\hline $\begin{array}{l}\text { Imports from } \\
\text { country } j \text { to } \\
\text { country } i\end{array}$ & $M_{j i}$ & $\begin{array}{l}\text { Imports from country } j \text { to } \\
\text { country } i\end{array}$ & $\begin{array}{l}\text { IMF, Direction of } \\
\text { Trade Statistics, } \\
\text { https://stats.ukdataservice. } \\
\text { ac.uk// }\end{array}$ \\
\hline $\begin{array}{l}\text { Exchange } \\
\text { Rate }\end{array}$ & $E$ & $\begin{array}{l}\text { Average of local currency } \\
\text { per dollar, euro, and yen }\end{array}$ & WDI \\
\hline $\begin{array}{l}\text { Real unit labour } \\
\text { costs }\end{array}$ & rulc & & {$\left[\right.$ rulc $\left.=w s * Y_{f} / Y\right]$} \\
\hline $\begin{array}{l}\text { Unit labour } \\
\text { Costs }\end{array}$ & ulc & & {$[u l c=\operatorname{rulc} * P]$} \\
\hline $\begin{array}{l}\text { Total factor } \\
\text { productivity }\end{array}$ & $\tau$ & $\begin{array}{l}\text { Total factor productivity: } \\
\text { total economy }\end{array}$ & AMECO Database \\
\hline
\end{tabular}




\section{Appendix B}

The diagonal elements of $E$ are calculated as in equations (2), (4), (9) and (10).

$$
E_{15 \times 15}=\left[\begin{array}{cccc}
\frac{\Delta C}{Y_{1}}+\frac{\Delta I}{Y_{1}}+\frac{\Delta N X}{\Delta \pi_{1}} & 0 & \cdots & 0 \\
0 & \ddots & \vdots & \vdots \\
\vdots & \ddots & \ddots & \vdots \\
0 & \cdots & \cdots & \frac{\frac{\Delta C}{Y_{15}}+\frac{\Delta I}{Y_{15}}+\frac{\Delta N X}{Y_{15}}}{\Delta \pi_{15}}
\end{array}\right]
$$

$H$ reflects the national multiplier:

$$
\begin{gathered}
H_{15 x 15}=\left[\begin{array}{cccc}
\frac{\Delta C_{1}}{\Delta Y_{1}}+\frac{\Delta I_{1}}{\Delta Y_{1}}-\frac{\Delta M_{1}}{\Delta Y_{1}} & 0 & \cdots & 0 \\
0 & \ddots & \cdots & \vdots \\
\vdots & \cdots & \ddots & \vdots \\
0 & \cdots & \cdots & \frac{\Delta C_{15}}{\Delta Y_{15}}+\frac{\Delta I_{15}}{\Delta Y_{15}}-\frac{\Delta M_{15}}{\Delta Y_{15}}
\end{array}\right] \\
H_{i i}=\frac{\partial C_{i}}{\partial Y_{i}}+\frac{\partial I_{i}}{\partial Y_{i}}-\frac{\partial M_{i}}{\partial Y_{i}}=e_{C Y, i} \frac{C_{i}}{Y_{i}}+e_{I Y, i} \frac{I_{i}}{Y_{i}}-e_{M Y, i} \frac{M_{i}}{Y_{i}} .
\end{gathered}
$$

$P$ is:

$$
\begin{gathered}
P_{15 x 15}=\left[\begin{array}{cccc}
0 & \frac{\partial\left(\frac{N X}{Y}\right)_{1}}{\partial \pi_{2}} \frac{M_{21}}{M_{1}} & \cdots & \frac{\partial\left(\frac{N X}{Y}\right)_{1}}{\partial \pi_{15}} \frac{M_{151}}{M_{1}} \\
\frac{\partial\left(\frac{N X}{Y}\right)_{2}}{\partial \pi_{1}} \frac{M_{12}}{M_{2}} & 0 & \cdots & \vdots \\
\vdots & \ddots & \ddots & \vdots \\
\frac{\partial\left(\frac{N X}{Y}\right)_{15}}{\partial \pi_{1}} \frac{M_{115}}{M_{15}} \frac{\partial\left(\frac{N X}{Y}\right)_{n}}{\partial \pi_{2}} \frac{M_{215}}{M_{15}} & \cdots & 0
\end{array}\right] \\
P_{i j}=\frac{\partial\left(\frac{N X}{Y}\right) i}{\Delta \pi_{j}} \frac{M_{j i}}{M_{i}}=\left(e_{P x j} \frac{1}{1-e_{p j}} \frac{Y f_{j}}{Y_{j}} \frac{1}{r u l c_{j}}\right) \frac{M_{j i}}{M_{i}}\left(e_{X P i} \frac{X_{i}}{Y_{i}}-e_{M P i} \frac{M_{i}}{Y_{i}}\right)
\end{gathered}
$$

$W$ is:

$$
W_{15 x 15}=\left[\begin{array}{cccc}
0 & e_{X Y r w, 1} \frac{X_{1}}{Y_{1}} \frac{Y_{2}}{Y_{w}} & \cdots & e_{X Y r w, 1} \frac{X_{1}}{Y_{1}} \frac{Y_{15}}{Y_{w}} \\
e_{X Y r w, 2} \frac{X_{2}}{Y_{2}} \frac{Y_{1}}{Y_{w}} & 0 & \cdots & e_{X Y r w, 2} \frac{X_{2}}{Y_{2}} \frac{Y_{15}}{Y_{w}} \\
\vdots & \ddots & \ddots & \vdots \\
e_{X Y r w, n} \frac{X_{15}}{Y_{15}} \frac{Y_{1}}{Y_{w}} & e_{X Y r w, n} \frac{X_{15}}{Y_{15}} \frac{Y_{2}}{Y_{w}} & \cdots & 0
\end{array}\right]
$$




\section{Appendix C}

Table C1. The marginal effect of a 1\%-point increase in the profit share on net exports

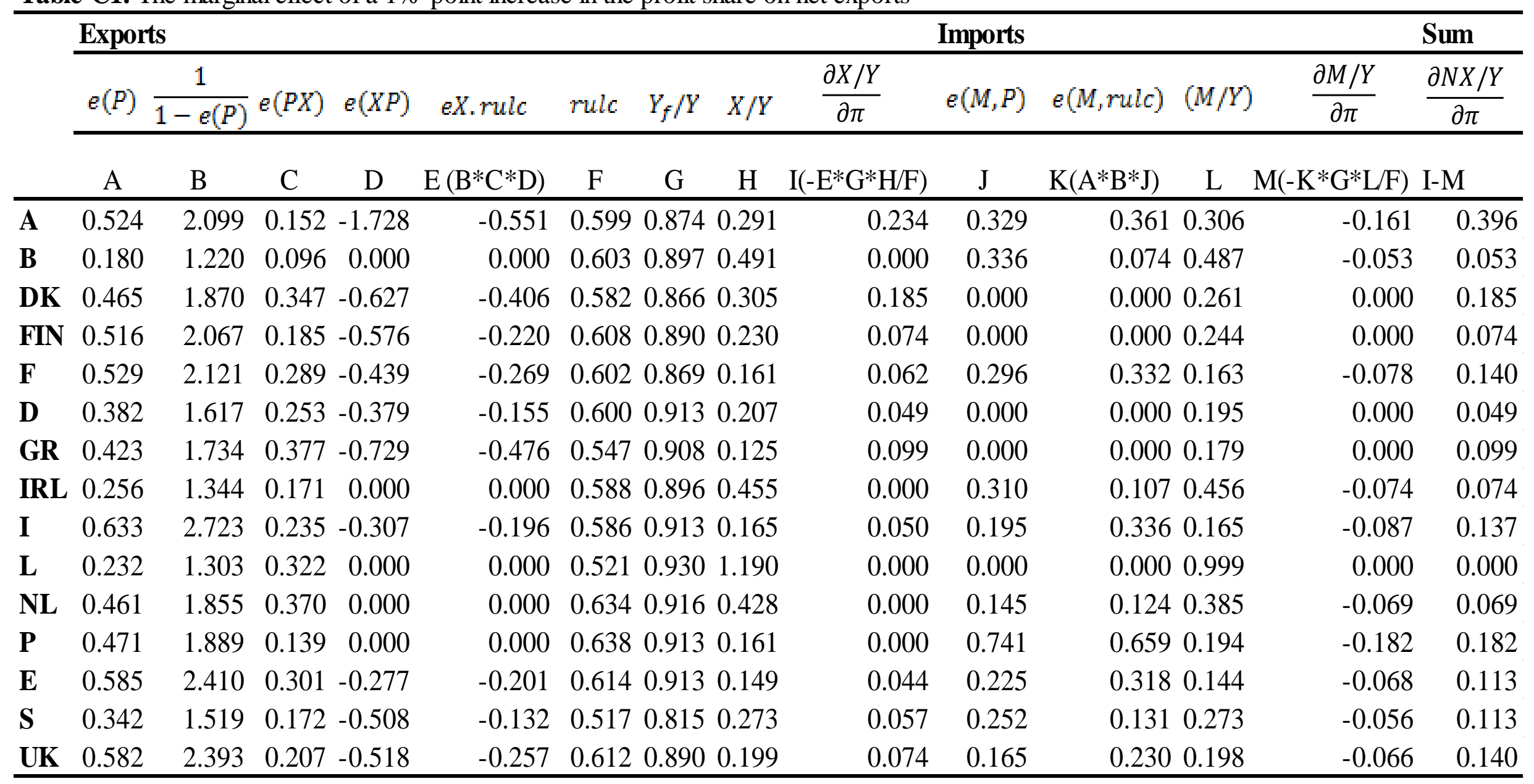

Notes : A = Austria, B = Belgium, DK = Denmark, FIN = Finland, F = France, D = Germany, GR = Greece, IRL = Ireland, I = Italy, L = Luxembourg, NL = Netherlands, P $=$ Portugal, $\mathrm{E}=$ Spain, $\mathrm{S}=$ Sweden, $\mathrm{UK}=$ United Kingdom

The marginal effect of a 1-\% point increase in the profit share on exports (and imports) is -1 the effect of a 1\%-point increase in the wage share 


\section{Appendix D}

Table D1. The total effect of an isolated 1\% point increase in the profit share on investment and net exports

\begin{tabular}{lrr}
\hline & Total effect on $\mathbf{I} \boldsymbol{Y}$ & Total effect on $\mathbf{N} / \boldsymbol{Y}$ \\
\cline { 2 - 3 } Austria & 0.046 & 0.321 \\
Belgium & 0.226 & -0.011 \\
Denmark & 0.274 & 0.064 \\
Finland & -0.097 & 0.175 \\
France & 0.049 & 0.181 \\
Germany & -0.123 & 0.204 \\
Greece & -0.425 & 0.309 \\
Ireland & 0.163 & 0.071 \\
Italy & 0.103 & 0.192 \\
Luxembourg & -0.021 & 0.101 \\
Netherlands & 0.053 & 0.157 \\
Portugal & -0.128 & 0.258 \\
Spain & -0.155 & 0.271 \\
Sweden & 0.062 & 0.201 \\
United Kingdom & -0.019 & 0.186 \\
\hline
\end{tabular}

Table D2. The total effects of a simultaneous $1 \%$ point increase in the profit share on investment and net exports

\begin{tabular}{lrr}
\hline & Total effect on $\mathbf{I} \boldsymbol{Y}$ & Total effect on $\mathbf{N} / \boldsymbol{Y}$ \\
\hline Austria & -0.070 & 0.210 \\
Belgium & 0.208 & -0.050 \\
Denmark & 0.214 & 0.020 \\
Finland & -0.132 & 0.150 \\
France & 0.009 & 0.149 \\
Germany & -0.138 & 0.181 \\
Greece & -0.473 & 0.280 \\
Ireland & 0.141 & 0.038 \\
Italy & 0.081 & 0.168 \\
Luxembourg & -0.033 & 0.071 \\
Netherlands & 0.045 & 0.128 \\
Portugal & -0.180 & 0.200 \\
Spain & -0.206 & 0.260 \\
Sweden & 0.012 & 0.156 \\
United Kingdom & -0.029 & 0.149 \\
\hline Average* & -0.039 & 0.162 \\
\hline
\end{tabular}

* Change in each country is multiplied by its share in EU15 GDP. 
Table D3. The effect of a 1\% point increase in the wage share on annual inflation and nominal unit labour costs

\begin{tabular}{|c|c|c|c|c|}
\hline & $\begin{array}{c}U L C \\
\Delta \log U L C / \Delta w s\end{array}$ & $\begin{array}{l}\text { Annual inflation } \\
\Delta \log P / \Delta w s\end{array}$ & $\begin{array}{l}1 \% \text { point } \\
\text { simultaneous } \\
\text { increase in the } \\
\text { wage share } \\
\text { Annual inflation } \\
\Delta \log P / \Delta w s\end{array}$ & $\begin{array}{l}\text { Differentiated } \\
\text { simultaneous } \\
\text { increase in the } \\
\text { wage share* } \\
\text { Annual inflation } \\
\Delta \log P / \Delta w s\end{array}$ \\
\hline Austria & 3.062 & 1.603 & 1.652 & 1.008 \\
\hline Belgium & 1.815 & 0.327 & 0.434 & 0.170 \\
\hline Denmark & 2.785 & 1.296 & 1.374 & 0.335 \\
\hline Finland & 3.025 & 1.562 & 1.637 & 1.626 \\
\hline France & 3.059 & 1.617 & 1.681 & 1.674 \\
\hline Germany & 2.461 & 0.939 & 1.036 & 1.028 \\
\hline Greece & 2.877 & 1.217 & 1.293 & 1.288 \\
\hline Ireland & 2.049 & 0.525 & 0.612 & 0.398 \\
\hline Italy & 4.242 & 2.684 & 2.749 & 2.744 \\
\hline Luxembourg & 2.325 & 0.541 & 0.605 & 0.592 \\
\hline Netherlands & 2.680 & 1.235 & 1.282 & 1.276 \\
\hline Portugal & 2.702 & 1.272 & 1.343 & 1.340 \\
\hline Spain & 3.581 & 2.095 & 2.177 & 2.173 \\
\hline Sweden & 2.396 & 0.818 & 0.911 & 0.887 \\
\hline United Kingdom & 3.477 & 2.025 & 2.092 & 2.085 \\
\hline Average** $^{*}$ & 2.836 & 1.317 & 1.392 & 1.242 \\
\hline
\end{tabular}

Notes: ${ }^{*}$ The differentiated increase in $\Delta$ ws is based on the scenario illustrated in table 8 divided by 5 to report the annual change in $\Delta$ ws and its effects on annual inflation.

** Change in each country is multiplied by its share in EU15 GDP. 
${ }^{1}$ The significant fall in the wage share has also been associated with increasing personal income inequality. Daudey and Garcia-Penalosa (2007) show that changes in the factor distribution of income are an important explanatory determinant of personal income inequality. Similarly, Atkinson (2009) argues that analysing changes in functional income distribution is crucial to understand trends of increasing dispersion in personal incomes. In the rest of the paper, we will focus on changes in functional income distribution, which allows us to aggregate the effects of increasing inequality on demand.

${ }^{2}$ For a comprehensive introduction into the debates concerning wage-led strategies see Lavoie and Stockhammer (2013).

${ }^{3}$ This methodology is used by the EC.

${ }^{4}$ Austria, Belgium, Denmark, Finland, France, Germany, Greece, Ireland, Italy, Luxembourg, Netherlands, Portugal, Spain, Sweden, United Kingdom.

${ }^{5}$ All variables will be used in logarithmic form due to the fact that they exhibit exponential growth.

${ }^{6}$ We do not take log of the real interest rate since it includes negative values.

${ }^{7}$ Rezai (2011) and von Arnim et al. (2012) present similar theoretical models with cross-country interactions.

${ }^{8}$ Stationarity tests are available upon request.

${ }^{9}$ The t-ratios reported by Banerjee et al. (1998) are used for the speed of adjustment coefficient to test whether there is cointegration among the variables.

${ }^{10}$ As a robustness check we converted elasticities into marginal effects using the sample mean as well as the latest value in 2013 to take into account possible effects coming from higher trade openness. Our results regarding the nature of the regimes remain robust and EU15 GDP remains wage-led.

${ }^{11}$ The results are robust when we use unadjusted wages or wage share as the regressors. Our mean differential is minus 0.312 and hence in alignment with previous studies, i.e. Marglin and Bhaduri (1992) find a savings differential of 0.37 for a sample of sixteen OECD countries.

${ }^{12}$ Belgium and Denmark are two exceptions in our sample.

${ }^{13}$ The IMF (2009) reports capital spending multipliers between 0.5 and 1.8 .

${ }^{14}$ The EC (2013) itself highlighted the incomplete pass-through of labour-cost moderation into prices. Wage cuts were not passed on to export prices but absorbed by increasing profit margins, particularly in the tradable sector.

${ }^{15}$ Results are available upon request.

${ }^{16}$ Results are available upon request.

${ }^{17}$ Barbosa-Filho and Taylor (2006) further decompose aggregate demand into individual components, rather than estimating behavioural equations.

${ }^{18}$ Capacity utilisation is usually defined as real GDP over potential GDP (e.g. Barbosa-Filho and Taylor (2006). Kiefer and Rada (2015) take the OECD output gap. However, as the authors note themselves, this methodology can be questioned due to both methodological and theoretical problems in measuring potential output or output gap.

${ }^{19}$ Finland, France, Germany, Ireland, Italy, Netherlands, Sweden, and the UK.

${ }^{20}$ Including 12 EU MS: Austria, Belgium, Denmark, Finland, France, Germany, Ireland, Italy, Netherlands, Spain, Sweden and United Kingdom.

${ }^{21}$ It should be noted that both scholars, in the Kaleckian and Goodwin tradition, agree on the partial effects, that is an increase in the wage share should increase consumption and depress investment. The disagreement is based on the relative size of the effects, and hence the total effects. However, as Stockhammer and Stehrer (2011) note, even though the Goodwin cycle based studies find profit-led demand regimes, it might not be due to reasons implied in Goodwin's theory of the business cycle. As the authors show, the link between investment and profits seems not to be strong. We also find that changes in investment are predominantly driven by changes in demand rather than in income distribution. The finding of a negative consumption differential is, however, robust across all countries in a wide range of studies.

${ }^{22}$ Blecker (2015) argues that the positive effects of increased profits on investment and net exports are stronger in the short run, while it appears that the negative effects on consumption are likely to be more significant in the long run. Therefore, he suggests that while there is evidence for demand to be profit-led in the short run it is not relevant to the impact of a change in the wage share on long-term economic performance.

${ }^{23}$ In our analysis, we first estimate ECM and then choose a difference specification if there is no significant error correction mechanism. Hence, the short run effects are arguably the same as the long run effects. We also calculate long-run coefficients in our difference specifications taking into consideration lagged effects of the explanatory as well as dependent variables.

${ }^{24}$ This implies a level effect, rather than a faster growth rate. GDP hence increases by an additional $0.30 \%$ in one year.

${ }^{25}$ Stockhammer et al. (2011) find that a change in rulc by $1 \%$ will come with an increase of $0.72 \%$ in inflation in Germany, and show that increased openness limits the ability of firms to pass on an increase in ulc. 